\title{
GSK-3 as potential target for therapeutic intervention in cancer
}

\author{
James A. McCubrey ${ }^{1}$, Linda S. Steelman ${ }^{1}$, Fred E. Bertrand ${ }^{2}$, Nicole M. Davis ${ }^{1}$, \\ Melissa Sokolosky ${ }^{1}$, Steve L. Abrams ${ }^{1}$, Giuseppe Montalto ${ }^{3}$, Antonino B. D'Assoro ${ }^{4}$, \\ Massimo Libra ${ }^{5}$, Ferdinando Nicoletti ${ }^{5}$, Roberta Maestro ${ }^{6}$, Jorg Basecke7,8, Dariusz \\ Rakus $^{9}$, Agnieszka Gizak ${ }^{9}$ Zoya Demidenko ${ }^{10}$, Lucio Cocco ${ }^{11}$, Alberto M. Martelli' \\ and Melchiorre Cervello ${ }^{12}$ \\ ${ }^{1}$ Department of Microbiology and Immunology, Brody School of Medicine at East Carolina University Greenville, NC, USA \\ 2 Department of Oncology, Brody School of Medicine at East Carolina University Greenville, NC, USA \\ ${ }^{3}$ Biomedical Department of Internal Medicine and Specialties, University of Palermo, Palermo, Italy \\ ${ }^{4}$ Department of Medical Oncology, Mayo Clinic Cancer Center, Rochester, MN, USA \\ ${ }^{5}$ Department of Bio-Medical Sciences, University of Catania, Catania, Italy \\ ${ }^{6}$ Experimental Oncology 1, CRO IRCCS, National Cancer Institute, Aviano, Pordenone, Italy. \\ 7 Department of Medicine, University of Göttingen, Göttingen, Germany \\ ${ }^{8}$ Sanct-Josef-Hospital Cloppenburg, Department of Hematology and Oncology, Cloppenburg, Germany \\ ${ }^{9}$ Department of Animal Molecular Physiology, Institute of Experimental Biology, Wroclaw University, Wroclaw, Poland \\ 10 Department of Cell Stress Biology, Roswell Park Cancer Institute, Buffalo, NY, USA \\ ${ }^{11}$ Dipartimento di Scienze Biomediche e Neuromotorie, Università di Bologna, Bologna, Italy \\ ${ }^{12}$ Consiglio Nazionale delle Ricerche, Istituto di Biomedicina e Immunologia Molecolare "Alberto Monroy", Palermo, Italy \\ Correspondence to: James A. McCubrey, email: mccubreyj@ecu.edu \\ Keywords: GSK-3, cancer stem cells, Wnt/beta-catenin, PI3K, Akt, mTOR, Hedgehog, Notch, Targeted Therapy, Therapy Resis- \\ tance, Mutations, Rapamycin \\ Received: April 24, $2014 \quad$ Accepted: May 28, $2014 \quad$ Published: May 28, 2014
}

This is an open-access article distributed under the terms of the Creative Commons Attribution License, which permits unrestricted use, distribution, and reproduction in any medium, provided the original author and source are credited.

\section{ABSTRACT}

The serine/threonine kinase glycogen synthase kinase-3 (GSK-3) was initially identified and studied in the regulation of glycogen synthesis. GSK-3 functions in a wide range of cellular processes. Aberrant activity of GSK-3 has been implicated in many human pathologies including: bipolar depression, Alzheimer's disease, Parkinson's disease, cancer, non-insulin-dependent diabetes mellitus (NIDDM) and others. In some cases, suppression of GSK-3 activity by phosphorylation by Akt and other kinases has been associated with cancer progression. In these cases, GSK-3 has tumor suppressor functions. In other cases, GSK-3 has been associated with tumor progression by stabilizing components of the beta-catenin complex. In these situations, GSK-3 has oncogenic properties. While many inhibitors to GSK-3 have been developed, their use remains controversial because of the ambiguous role of GSK-3 in cancer development. In this review, we will focus on the diverse roles that GSK-3 plays in various human cancers, in particular in solid tumors. Recently, GSK-3 has also been implicated in the generation of cancer stem cells in various cell types. We will also discuss how this pivotal kinase interacts with multiple signaling pathways such as: PI3K/PTEN/Akt/mTORC1, Ras/Raf/MEK/ERK, Wnt/beta-catenin, Hedgehog, Notch and others. 


\section{Multiple Roles of GSK-3 in Cellular Physiology and Human Health}

GSK-3 is a serine (S) /threonine (T) kinase. GSK3 was initially isolated and purified from rat skeletal muscle as a kinase that phosphorylated and inactivated glycogen synthase (GS), the last enzyme in glycogen biosynthesis [1,2]. Thus GSK-3 was identified initially to have important roles in metabolism. GSK-3 is believed to be an important regulatory enzyme in many diseases and disorders such as: cancer and aging (cancer stem cells, cellular senescence, control of stem cell pluripotency and differentiation), immune disorders, metabolic disorders (atherosclerosis, diabetes, and heart disease), neurological disorders (Alzheimer's, amyotrophic lateral sclerosis [ALS], bipolar disorder, mood disorders, Parkinson's, and schizophrenia), and other maladies [3-26]. GSK-3 may be a key therapeutic target for these and other diseases [1126].

GSK-3 has been implicated to play roles in cancers which are resistant to chemo-, radio-, and targeted therapy [7]. Targeting GSK-3 may be a means to overcome the resistance of these cancers to certain chemotherapeutic drugs, radiation and small molecule inhibitors [8-10].

\section{GSK-3alpha and GSK-3beta}

The GSK-3 gene family consists of two highly conserved kinases GSK-3alpha and GSK-3beta. However, the two molecules have distinct roles and one can not compensate for the loss of the other. In fact, expression of GSK-3alpha did not rescue embryonic lethality in mice in which GSK-3beta gene has been disrupted. GSK3A and GSK3B encode 51 and $47 \mathrm{kDa}$ proteins respectively [28]. The GSK-3alpha isoform has a glycine-rich extension at its amino terminus. GSK-3alpha and GSK-3beta display $98 \%$ sequence identity in their kinase domains but only $36 \%$ identity in their carboxyl termini [29]. GSK-3alpha and GSK-3beta are considered active in non-stimulated cells. Both GSK-3-alpha and GSK-3beta exhibit strong preferences for primed substrates; this means they prefer substrates which have already been phosphorylated by other kinases [(e.g., casein kinase-1 (CK1), mitogen activate protein kinases (MAPK) [extracellular regulated kinase (ERK), p38 ${ }^{\mathrm{MAPK}}$, and c-Jun N-terminal kinase $(\mathrm{JNK})$ ], 5' adenosine monophosphate-activated protein kinase (AMPK)] and others. The GSK-3 kinases phosphorylate greater than 40 proteins including over 12 transcription factors [30]. Figure 1 presents a diagram indicating some of the substrates of GSK-3.

\section{Differences between GSK-3alpha and GSK-3beta.}

GSK-3alpha and GSK-3beta are structurally similar, however, they are not functionally identical and they have some different substrate specificities. These GSK-3beta knock-out mice die around embryonic day 16 due to liver degeneration caused by hepatocyte apoptosis [27]. Furthermore, GSK-3beta activity was essential for TNF-
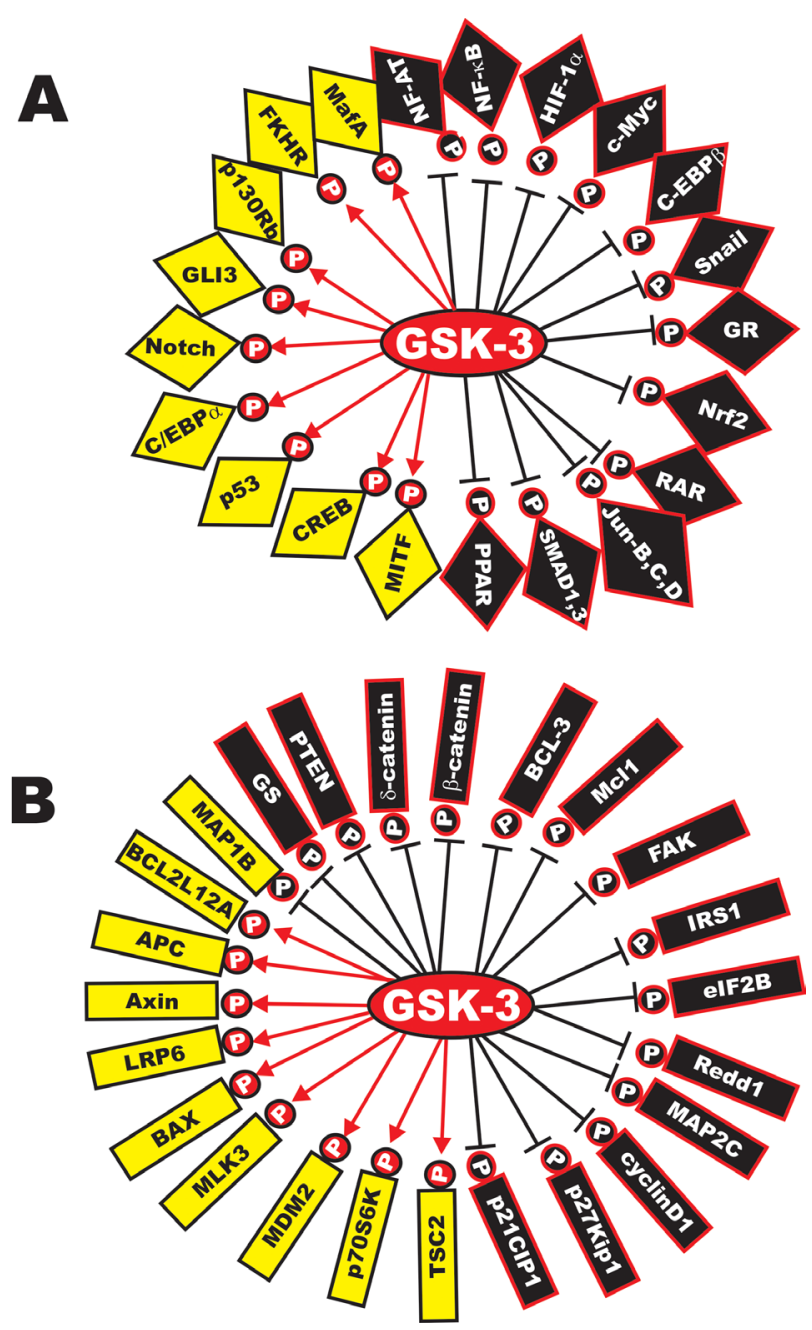

Figure 1: Diversity of GSK-3 Substrates. Panel A. Transcription factors phosphorylated by GSK-3. Transcription factors activated by GSK-3 are indicated in yellow diamond type shape with black lettering and P's in red circles. Transcription factors inactivated by GSK-3 are indicated in black diamonds with white lettering and P's in black circles. Panel B. Various proteins phosphorylated and activated by GSK-3 are indicated in yellow rectangles with black lettering and P's in red circles. Various proteins phosphorylated and inhibited by GSK-3 are indicated in black rectangles with white lettering and P's in black circles. In some cases, an individual protein may be activated or inhibited by GSK-3 phosphorylation. This diagram is intended to provide the reader an idea of the diversity of GSK3 substrates and the roles of GSK-3 in regulating the activity of these substrates. 
alpha-induced NF-kappaB activation in hepatocytes. In contrast GSK-3alpha knockout mice are viable but exhibited enhanced glucose and insulin sensitivity and reduced fat mass. GSK-3alpha knock-out mice elicited metabolic and neuronal developmental abnormalities [31,32]. GSK-3alpha and GSK-3beta have different substrate preferences in the brain [33] and likely other tissues. Thus, GSK-3 isoforms exhibit tissue-specific physiologically important functions which are may not be overlapping and sometimes may be different. These and other studies indicate that there are rationales for the specific targeting of GSK-3alpha or GSK-3beta in certain diseases.

Most biochemical studies have focused on GSK3beta; however, some studies have demonstrated roles for GSK-3alpha in drug resistance and cancer stem cells. GSK-3alpha was recently identified as a key target in acute myeloid leukemia (AML) [34]. Thus the generation of isoform specific inhibitors could result in more specific treatments.

\section{GSK-3 Activity is Controlled by Phosphorylation/ Dephosphorylation}

GSK-3alpha and GSK-3beta are expressed ubiquitously and highly conserved. Their activities are

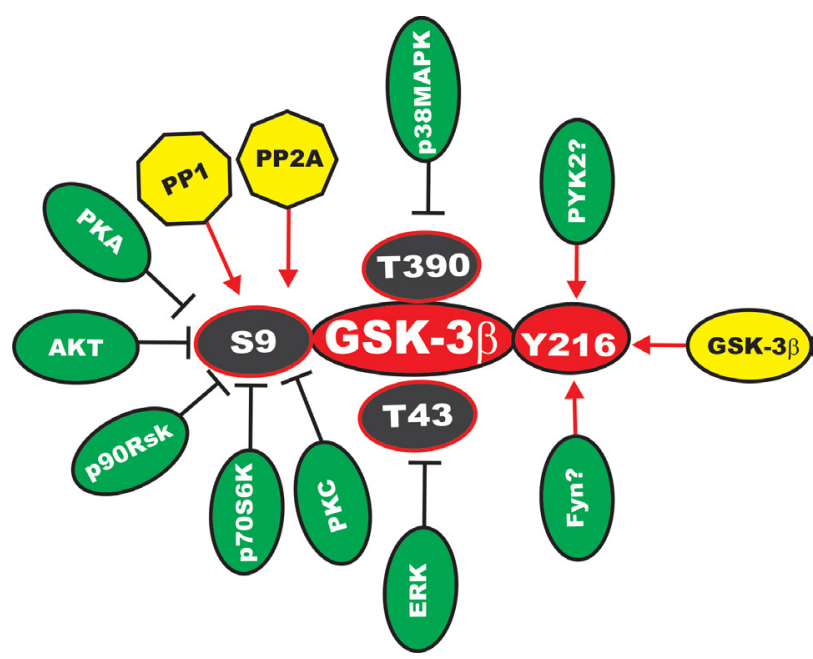

Figure 2: Sites of Phosphorylation of GSK-3beta which Regulate its Activity. Kinases which phosphorylate GSK-3beta which result in its inactivation are indicated by yellow ovals with inhibitory black lines. Phosphatases such as PP1 and PP2A have been reported to dephosphorylate S9 which could activate GSK-3beta are indicated in yellow octagons with black arrows. The Y216 site of GSK-3beta has been reported to be phosphorylated by Fyn and PYK2; these are indicated by green ovals with red arrows. Finally, GSK3beta may autophosphorylate itself at Y216, which would lead to its activation; this is indicated by a yellow oval with a red arrow. This figure is provided to give the reader an idea of the complexity of regulation of GSK-3 by various kinases and phosphatases. regulated by diverse stimuli and signaling pathways. The activity of GSK-3alpha is extinguished by phosphorylation at S21, while GSK-3beta activity is silenced by phosphorylation at S9. These phosphorylation events at S21 and S9 inhibit GSK-3 activity by inducing a pseudosubstrate conformation in the substrate docking motifs of GSK-3alpha and GSK-3beta respectively [2830]. Phosphorylation of GSK-3beta at S9 leads to its inactivation by proteasomal degradation and has been associated with many pathological conditions, including cancer. Various kinases phosphorylate GSK-beta at S9 including protein kinase A (PKA), protein kinase $\mathrm{B}$ (PKB a.k.a Akt), p90 ribosomal S6 kinase (p90 ${ }^{\text {Rsk }}$ ), p70 ribosomal S6 kinase (p70S6K) [28-30, 35-39]. A diagram depicting sites of regulation of GSK-3beta is presented in Figure 2.

Insulin signaling results in activation of Akt and subsequent phosphorylation and inactivation of GSK-3beta (S9) and GSK-3alpha (S21) [37]. Epidermal growth factor (EGF), platelet derived growth factor (PDGF) and other growth factors also induce the phosphorylation of GSK3beta (S9) and GSK-3alpha (S21) by the activated Raf/ MEK/ERK/p90 ${ }^{\text {Rsk1 }}$ signaling pathway [39]. Other signaling pathways induce the phosphorylation and inactivation of GSK-3beta and GSK-3alpha by phosphorylation at S9 and S21 respectively [37-42]. Thus GSK-3 activity is often shut off after exposure to mitogenic/growth factors.

Elucidation of the crystal structure of GSK-3 has helped to reveal how the phosphorylation of GSK-3beta and GSK-3alpha at S9 and S21 respectively results in their inhibition [29]. When either S9 or S21 of GSK3beta or GSK-3alpha respectively, are phosphorylated, a primed pseudosubstrate is created which folds and binds the positively-charged pocket. This folding prevents the phosphorylation of substrates as the catalytic groove is blocked. This is a competitive mechanism of inhibition and if elevated concentrations of the substrates are present, they will out-compete the pseudosubstrate and the substrates will be phosphorylated [43].

Arginine 96 of GSK-3beta is a critical component of the positive pocket which binds primed substrates. Mutation of arginine (R) 96 of GSK-3beta to alanine (A) (R96A) has consequences on the ability of GSK-3beta to phosphorylate primed vs. unprimed substrates. Priming of substrates usually occur $\mathrm{N}+4$ from the site where GSK-3 phosphorylates the substrate [29]. Namely if the substrate is primed, which is a preference of the GSK-3s; they will not be phosphorylated when R96 is mutated to A, whereas if they are not primed they will be phosphorylated. The R96A mutation disrupts the GSK-3beta pocket of positive charge and prevents the phosphorylation of the primed substrates. The R96A mutation prevented the S9phosphorylated GSK-3beta pseudosubstrate from folding back and resulted in the phosphorylation of unprimed substrates even when GSK-3beta was phosphorylated at S9 [44]. A peptide of eleven amino acids corresponding to 
the phosphorylated amino terminal of GSK-3beta inhibited competitively the phosphorylation of both primed and unprimed substrates [43]. In contrast, a truncated version of this peptide only inhibited phosphorylation of primed substrates. These results point to different approaches to specifically inhibit the ability of GSK-3beta to phosphorylate different substrates.

Phosphorylation of GSK-3beta at tyrosine (Y) 216 also regulates it activity and may activate GSK3beta. This may be due to autophosphorylation [45] but it may also be mediated by kinases such as Src. Y279 is the corresponding residue present in GSK3alpha. Phosphorylation of GSK-3beta at Y216 may be constitutive in resting cells $[45,46]$. Apoptotic stimuli can increase Y216 phosphorylation of GSK-3beta indicating roles for GSK-3beta in cell death [47-52]. The prolinerich tyrosine kinase 2 (PYK2) may phosphorylate GSK3alpha and GSK-3beta at Y216 and Y270 respectively [53]. PYK2 controls lysophosphatidic acid-induced activation of GSK-3 which regulates the phosphorylation of microtubule-associated proteins. PYK2-mediated activation of GSK-3 destabilized microtubules during actinomyosin-driven neurite retraction $[54,55]$. The Fyn tyrosine kinase also phosphorylates GSKs $[45,56]$. The MAPK family also regulates the activity of GSK-3s. p38MAPK phosphorylates GSK-3beta at S389/T390 [57]. ERK phosphorylation of GSK-3beta at T43 has been proposed to induce a conformational change in GSK-3 which alters its activity [30]. Finally protein phosphatases (e.g., $\mathrm{PP} 2 \mathrm{~A}, \mathrm{PP} 1)$ have important roles in regulation of GSK-3 activity by removing the phosphate on S9 as well as other regulatory residues [58,59]. In addition, GSK-3s likely have protein phosphatases as substrates (e.g., PP1G) [30].

\section{Biochemical Functions of GSK-3}

GSK-3beta represses the expression of certain immediate response genes in quiescent cells [60]. GSK3 can alter the activity of proteins important in RNA translation such as p70S6K $[61,62]$. The GSK-3-related yeast protein Mck1 can inhibit the activity of the major mitotic cyclin-Cdk complex $\mathrm{Clb} 2-\mathrm{Cdk} 1$ and regulate cellular division [63]. A diagram illustrating some of the targets of GSK-3 was presented in Figure 1.

Cell cycle arrest at the $\mathrm{G}_{1}$ phase occurs upon inhibition of GSK-3 and subsequent activation of p2 $7^{\mathrm{Kip}-1}$ [64]. GSK-3 can also phosphorylate $\mathrm{p} 21^{\mathrm{Cip} 1}$ at T57. This phosphorylation event lead to the proteasomal degradation of $\mathrm{p} 21^{\mathrm{Cip} 1}[65]$. In contrast, lack of GSK-3-mediated phosphorylation of cyclin D1 at T286 and cyclin E at S380 suppressed their nuclear export and degradation [66-68].

GSK-3 has many direct and indirect effects on cell proliferation. GSK-3 can regulate the activity of transcription factors. Thus it can has important regulatory roles on cellular growth [69]. The growth arrest and DNA damage 45 (GADD45) and GADD153 genes encode tumor suppressors which are checkpoint inhibitors. GSK-3beta can regulate the activity of the tumor suppressor TP53, which can modulate GADD45 transcription. GADD45 is induced by DNA damage and its expression is regulated by TP53. The cell cycle is arrested when GADD45 is induced. c-Myc can also influence the expression of the GADD43 and GADD153 genes. GSK-3 can regulate c-Myc activity [70]. c-Myc can also modulate the expression of cell division cycle 25A (CDC25) gene which encodes an important cell cycle regulator gene [69].

GSK-3 regulates the activity of other transcription factors including NF-kappaB [69,71,72], Snail [73,74], Notch [75,76], forkhead [77], CAAT-enhancer binding protein (C/EBP) [78]. GSK-3 modifies the activity of other transcription factors frequently implicated in cancer including: activation protein 1 (AP1) [79] and c-Myc [70]. GSK-3beta can phosphorylate NF-kappaB at S468 which promoted its proteasomal degradation [80]. GSK-3beta also interacted with I-kappaBalpha in epithelial cells [81]. Other studies have indicated that GSK-3beta suppressed NF-kappaB activity by preventing the degradation of IkapaBalpha [82]. Thus GSK-3beta can regulate NFkappaB activity by multiple mechanisms.

GSK-3beta also affected TP53 activity [83,84]. TP53 and miRNA34 can in turn regulate Snail, which is also regulated by GSK-3 [85]. Loss of TP53 activity resulted in decreased miRNA34 levels which bound to the 3'ends of Snail mRNA and suppressed its expression. Hence in the absence of functional TP53, Snail activity was increased and epithelial-mesenchymal transition (EMT) was promoted. GSK-3 regulated this axis. TP53 and miRNA34 are normally suppressors of Wnt/beta catenin signaling [86].

NF-kappaB and GSK-3 regulate the focal adhesion kinase (FAK) [87]. Some extracellular matrix proteins are indirect targets of Snail, c-Myc and NF-kappaB [73,74]. Certain matrix metalloproteinases are transcriptionally regulated by NF-kappaB, C/EBPs and Snail. Furthermore Snail represses E-cadherin transcription [83]. GSK-3 phosphorylates Snail which leads to its nuclear export $[74,89]$. Phosphorylation of Snail by GSK-3 can result in the cytoplasmic translocation of Snail and lead to increased E-cadherin expression in oral cancer [90]. Stabilization of Snail protein, by increased GSK-3beta phosphorylation, is also observed during EMT in different solid cancer types [91-93]. Snail stabilization and EMT, through enhanced Akt activity and subsequent GSK-3 $\beta$ phosphorylation, is induced by hepatitis $\mathrm{B}$ virus $\mathrm{X}$ protein $(\mathrm{HBx})$ in $\mathrm{HBV}$-associated hepatocarcinogenesis and in hepatocellular carcinoma (HCC) patients which have amplification and overexpression of the novel oncogene Maelstrom (MAEL) [94,95].

The activity of apoptotic and anti-apoptotic family members are also regulated by GSK-3. Bcl-2 expression is inhibited by GSK-3beta phosphorylation of CREB 
[96]. The myeloid cell leukemia sequence 1 (Mcl-1) anti-apoptotic factor [97-99] is also regulated by GSK3. However, some studies indicate that GSK-3 activity may not be required for Mcl-1 degradation [100]. GSK3 stabilizes the expression of certain anti-apoptotic Bcl2 family members [101-102]. Gsk-3beta can regulate BCL2L12a anti-apoptotic signaling. BCL2L12A is an anti-apoptotic Bcl-2 family member which is expressed at high levels in glioblastoma [103]. When BCL2L12A is phosphorylated at S156 by GSK-3beta, it is stabilized and has increased anti-apoptotic effects with regards to treatment with the drug staurosporin. The effects of BCL2L12A expression on apoptosis were inhibited when the cells were treated with the GSK-3 inhibitor lithium chloride. Interestingly, GSK-3beta and Mcl-1 inactivation have been shown to be part of the mechanism of action of the anesthetic propofol [104].

The expression of the myeloblastosis transcription factor (c-Myb) is also regulated by GSK-3beta. c-Myb is important in the regulation of $B C L 2$ transcription. Suppression of GSK-3beta inhibited the expression of c-Myb. c-Myc can form a complex with the lymphoid enhancer-binding factor 1 (LEF-1) transcription factor and bind the promoter regions of the BCL2 and BIRC5 (survivin) genes which leads to the prevention of apoptosis [105].

Pro-apoptotic Bim is also a target of GSK3beta. Suppression of GSK-3beta resulted in increased expression of Bim in pancreatic cancer cells, but not in non-transformed pancreatic epithelial cells. This regulation of Bim is thought to occur via JNK-dependent mechanisms which involve Bim transcription [106].

Bcl-2-associated $\mathrm{X}$ protein $(\mathrm{Bax})$ can be phosphorylated by GSK-3beta in neuronal cells. Bax phosphorylation by GSK-3beta stimulated the mitochondrial localization of Bax. This localization of Bax had pro-apoptotic consequences [107]. TP53 activity in colorectal cancer cells (CRCs) can be in part regulated by GSK-3beta. These effects of GSK-3beta on TP53 lead to increased levels of Bax [108]. GSK-3 can activate the v-maf musculoaponeurotic fibrosarcoma oncogene homolog (MAF) transcription factor which enhanced its transforming activity [109]. GSK-3 also serves to regulate the levels of beta-catenin, a key molecule involved in normal development as well as cancer progression [110119].

Thursday Inhibtition of GSK-3beta activity was also shown to be critical for association of two metabolic enzymes: hexokinase II [120 PMID: 21430642] and muscle isoform of fructose-1,6-bisphosphatase (FBP2) [121 PMID: 22154964] with mitochondria which results in the protection of the organella against stress stimuli and the promotion of ATP synthesis.

\section{GSK-3 as a Tumor-Promoter}

GSK-3 has various roles in cancer which even after years of study remain complex and controversial. GSK-3 may play positive roles in cell proliferation and its aberrant expression as a tumor promoter. GSK-3 is overexpressed in various tumor types including; colon, liver, ovarian and pancreatic tumors [122-124].

Suppression of GSK-3beta expression inhibited pancreatic cancer growth and angiogenesis [125]. Decreased levels of Bcl-2 and vascular endothelial growth factor (VEGF) were detected in cells which had GSK-3beta knocked-down. GSK-3 inhibitors may be appropriate for treatment of these types of tumors exhibiting GSK-3 overexpression in which GSK-3 is acting as a tumor promoter.

\section{GSK-3 as a Tumor-Suppressor}

GSK-3 also functions as a tumor suppressor. GSK-3 can suppress the Wnt/beta-catenin pathway by phosphorylating beta-catenin which results in the ubiquitin/proteasome-dependent degradation of betacatenin. Introduction of kinase-inactive (KI), GSK-3beta mutants which presumably functioned as inhibitors of the endogenous wild-type (WT) GSK-3beta protein stimulated Wnt signaling and mammary tumorigenesis [126]. Enforced expression of kinase-dead (KD) GSK3beta, which presumably functioned as inhibitors of the WT GSK-3beta protein, promoted tumorigenesis of breast and skin tumors [127]. Overexpression of constitutively-active GSK-3beta mutants, in some studies, increased chemosensitivity, cell cycle arrest, and reduced tumorigenicity of breast cancers [128130]. Pharmacological inhibition of GSK-3 induced EMT and invasion in breast cancer [89]. In these studies suppression of GSK-3 lead to stabilization of beta-catenin which resulted in elevated c-Myc, cyclin-B1 and survivin expression and promoted proliferation and tumorigenesis. There is perhaps a fine balance with GSK-3 whether it functions a tumor suppressor or tumor inducer.

Expression of KI GSK-3beta in murine mammary glands can function as DN mutation and promote breast cancer development by stabilizing beta-catenin protein expression [126]. The GSK-3beta KI construct stabilized beta-catenin expression and increased its nuclear localization and upregulated the expression of betacatenin target genes such as cyclin D1. The GSK-3beta KI gene was driven by a mouse mammary tumor virus long terminal repeat (LTR) which contains sequences that promoted high level expression of the introduced gene in the mammary tissue. Expression of the GSK-3beta $\mathrm{KI}$ mutant resulted in stabilized beta-catenin expression, beta-catenin nuclear localization, activation of a TCF/ LEF-dependent reporter construct and increased cyclin-D 
mRNA and protein levels.

Cyclin D1 was detected at high levels in approximately $50 \%$ of breast cancer patients examined. However only $15-20 \%$ of these patient samples had amplification of cyclin D1 [131-133]. beta-catenin transactivation has been associated with cyclin D1 overexpression in breast cancer [134]. Aberrant GSK3beta expression may lead to increased beta-catenin transcription which increases cyclin D1 expression. Cyclin D1 expression is increased in certain breast cancer patients

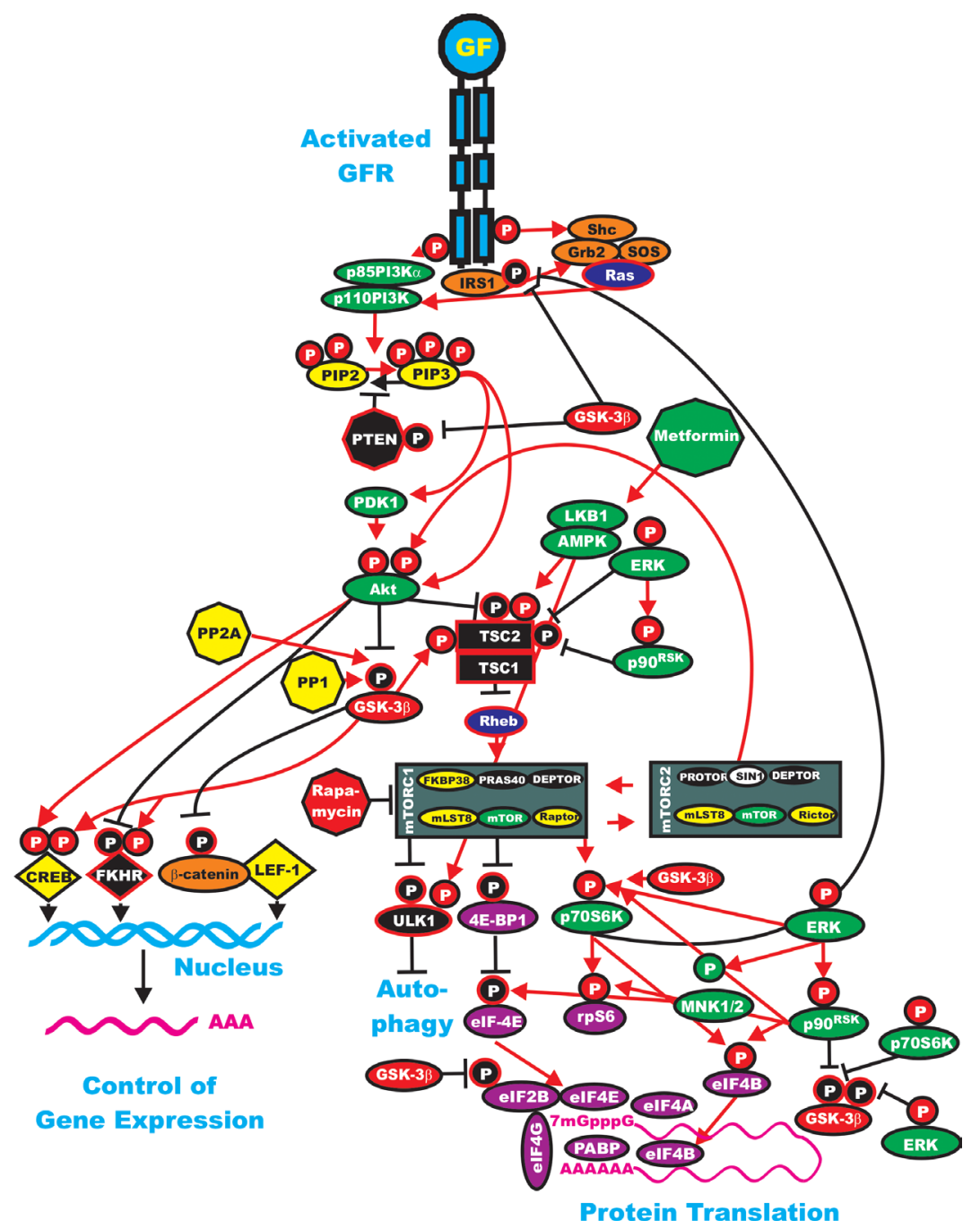

Figure 3: Interactions of GSK-3 with the Ras/PI3K/PTEN/Akt/mTOR and Ras/Raf/MEK/ERK Pathways. Some of the regulatory interactions between GSK-3 and Ras/PI3K/PTEN/Akt/mTOR and Ras/Raf/MEK/ERK pathways are indicated. An activated growth factor receptor is indicated in blue. Ras and Rheb are indicated in dark blue ovals. IRS1, Shc, Grb2, Sos and beta-catenin are indicated in orange ovals. Kinases are indicated in green ovals with the exception of GSK-3beta which is indicated in a red oval. The p85 regulatory subunit of PI3K is indicated in a green oval. The phosphatases which inhibit steps in this pathway are indicated in black octagons. The phosphatases PP2A and PP1 which may activate GSK-3 are indicated in yellow octagons. NF1, TSC1 and TSC 2 are indicated in black squares. PIP2 and PIP3 are indicated in yellow ovals. The mTORC1 inhibitor is indicated in a red octagon. The AMPK activator Metformin is indicated in a green octagon. mTOR interacting proteins which positively regulate mTOR activity are indicated in yellow ovals. mTOR interacting proteins which negatively regulate mTOR activity are indicated in black ovals. Transcription factors activated by either ERK or Akt phosphorylation are indicated in yellow diamonds. The FKHR transcription factor that is inactivated by Akt phosphorylation is indicated by a black diamond and a white P in a black circle. FKHR is also activated by GSK-3beta phosphorylation which is indicated by a white P in a red circle. beta-catenin is indicated in an orange oval. mRNA initiation factors and proteins associated with the ribosome are indicated in magenta ovals. mTORC1 phosphorylates the unc-51-like kinase 1 (ULK1) which results in the suppression of autophagy. ULK1 is indicated in a black oval. In contrast, AMPK activates both ULK1 and autophagy as well as TSC activity. Proteins involved in the regulation of translation are indicated in purple ovals. Red arrows indicate activating events in pathways. Black arrows indicate inactivating events in pathway. Activating phosphorylation events are depicted in red circles with Ps with a black outlined circle. Inactivating phosphorylation events are depicted in black circles with Ps with a red outlined circle. This figure is provided to give the reader an idea of the complex interactions of GSK-3 with various signaling molecules in the Ras/PI3K/PTEN/Akt/mTOR and Ras/Raf/MEK/ERK pathways which are key in regulating cellular proliferation survival and often become dysregulated in cancer. 
as GSK-3beta regulates cyclin D1 turnover.

Overexpression of the tumor suppressor Axin gene in transgenic mice lead to decreased expression of cyclin D1 and increased apoptosis in mammary epithelia. In addition, impaired lymphoid development was observed in these [135]. CK2alpha overexpression in transgenic mice resulted in mammary tumorigenesis as under these circumstances CK2alpha promoted Wnt signaling [136].

We observed that the GSK-3(KD) mutant induced doxorubicin resistance in MCF-7 breast cancer cells [137]. However, in the same experiments the constitutivelyactive A9 GSK-3beta also made the cells slightly more doxorubicin resistant than cells transfected with the GSK-3beta (WT) construct. Moreover, the GSK3 beta(KD) construct made the MCF-7 cells more resistant to tamofixen than the cells transfected with the GSK3 beta(WT) construct. However different results were observed with rapamycin which blocks mTORC. MCF-7 cells transfected with the GSK-3beta(KD) construct were hypersensitive to rapamycin while cells transfected with the constitutively-active GSK-3beta (A9) construct were resistant to rapamycin. The cells containing the GSK3beta(KD) construct were more sensitive to the GSK-3 inhibitor lithium than cells harboring GSK-3beta(WT) construct.

\section{Mutations in GSK-3 Targets}

Since GSK-3 is a kinase with a specific recognition motif present in substrate proteins that it phosphorylates, mutations can occur in certain genes which prevent GSK-3-mediated phosphorylation of the proteins they encode. The mutant proteins may have altered half-lifes as compared to the WT proteins as they may not be subject to proteasomal degradation. For example, mutations

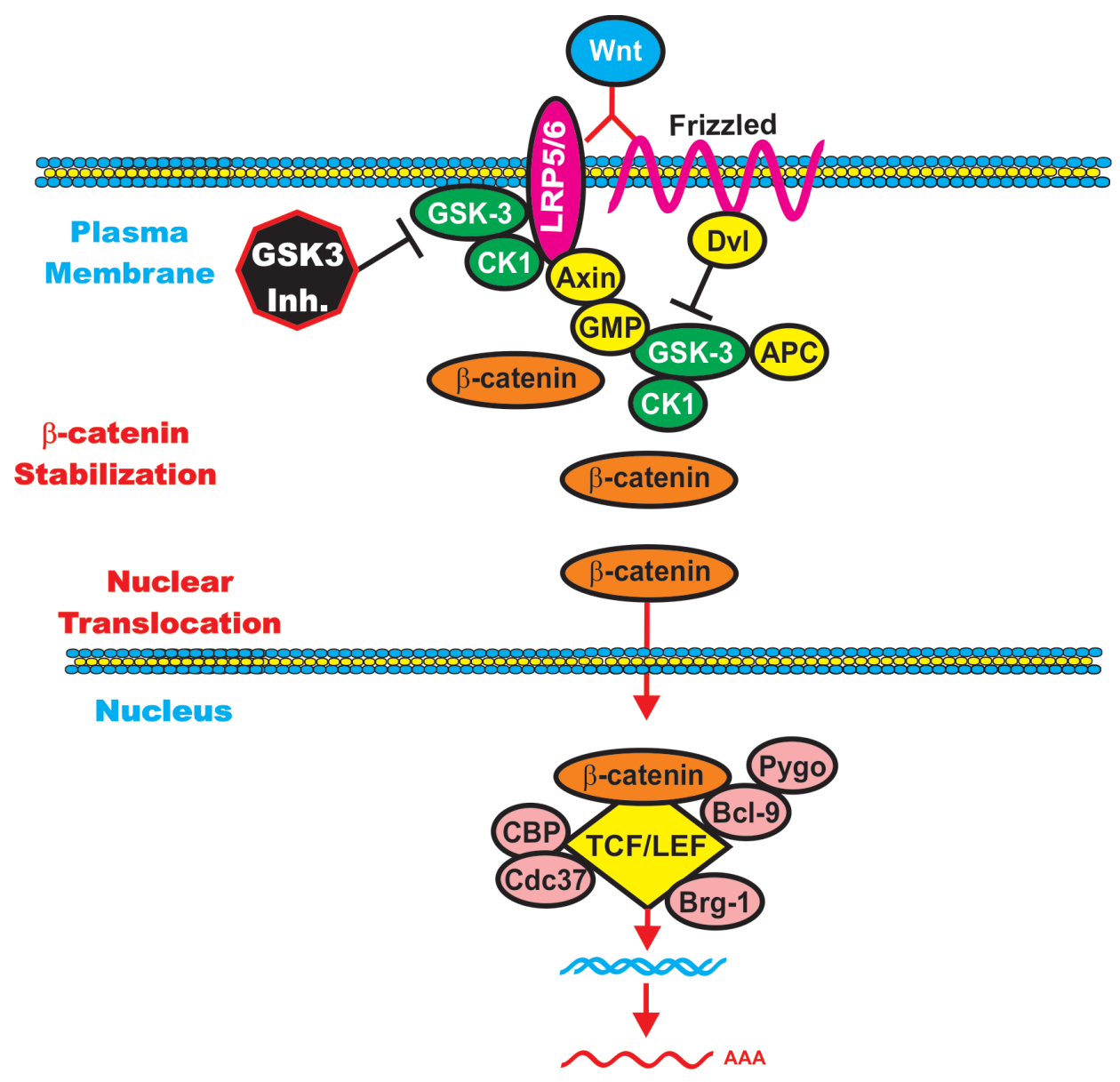

Cyclin D1, c-Myc, PPAR $\delta$, DKK1, Axin2, c-Jun, VEGF and other genes

Figure 4: Wnt/beta-catenin Induced Gene Expression is Modulated by GSK-3. When Wnt is present beta-catenin is stabilized and can induce gene transcription. Wnt binds its coreceptors Frizzled (Fz) and LRP5/LRP6. The Fz transmembrane receptor is indicated by a squiggly line to indicate its spanning the membrane seven times. The LRP5 and LRP6 transmembrane receptors are indicated by a red oval. Various molecules which interact with the receptors and GSK-3 and CK1 are indicated in yellow ovals. In the presence of Wnt, betacatenin is stabilized and induces gene expression by complexing with various transcription factors such as TCF/LET, which are indicated by yellow diamonds. Various proteins which interact with the transcription factor complexes are indicated in pink circles. 
changing T58 of c-Myc prevented the ability of GSK-3 to phosphorylate c-Myc and thus suppressed its proteasomal degradation [138-141]. Genetic mutations changing the GSK-3 phosphorylation sites S33, S37, S45 or T41 present in beta-catenin prevented the ability of GSK3 beta to phosphorylate beta-catenin and thus inhibited its proteasomal degradation. Likewise mutations at S45 of beta-catenin prevented CKI from performing the priming phosphorylation, thus GSK-3 was unable to phosphorylate the other residues of beta-catenin. Thus mutations at GSK3 or CKI phosphorylation sites which prevent the ability of GSK-3 or CKI to phosphorylate target proteins which can under certain circumstances be oncogenic [142-145].

\section{The PI3K/PTEN/Akt/mTOR Pathway and GSK- 3.}

The PI3K/PTEN/Akt/mTOR pathway and GSK3 can cross-regulate each other at various points. Some of the interactions between GSK-3 and the PI3K/PTEN/ $\mathrm{Akt} / \mathrm{mTOR}$ pathway are presented in Figure 3. As stated previously, GSK-3beta is negatively by Akt when it is phosphorylated on S9. GSK-3beta is then inactive.

The PI3K/PTEN/mTOR pathway is also involved in cancer initiation, metastasis, drug resistance, and sensitivity to therapy [146-152]. PI3K p110 catalytic subunit (PIK3CA) mutations may be driver mutations in certain cancers responsible for metastasis [153]. Novel PI3K-alpha inhibitors have been isolated and they inhibit metastasis [154]. Most PI3K inhibitors are cytostatic rather than cytotoxic and it has been questioned whether treatment with a single PI3K inhibitor will be effective [155].

The PI3K/PTEN/Akt/mTORC1 pathway is important in c-Myc expression in Burkitt's lymphomagenesis in germinal center B cells [156]. The $\mathrm{PI} 3 \mathrm{~K} / \mathrm{PTEN} / \mathrm{Akt} / \mathrm{mTORC} 1$ pathway is also an emerging target for mantle cell lymphoma as this cascade is upregulated in this cancer [157]. Disruption of PTEN and TP53 activity in the thyroid has recently been shown to result in murine models of anaplastic thyroid carcinomas. This model could be important for the development of approaches to target human thyroid carcinomas [158]. The PI3K/PTEN/Akt/mTORC1 pathway is a key pathway involved in many cancers including gliomas often due to aberrant PTEN expression. Recently it has been shown that reduction of $P I K 3 C A$ or PI3K p 85 regulatory subunit $(P I K 3 R A)$ cell proliferation impedes proliferation, migration, and invasion in glioblastoma multiforme cells [159]. In contrast to PIK3CA, PIK3CB (PI3K p110-beta catalytic subunit) is oncogenic in its WT configuration when it is overexpressed in certain conditions. $P I K 3 C B$ can act like an oncogenic mutant of PIK3CA [160].

PIK3CD (PI3K-delta p110 catalytic subunit) has been shown to have roles in BCR-ABL-mediated chronic lymphocytic leukemia (CLL) by turning off breakpoint cluster region (BCR) signaling [162]. Elevated PI3K signaling has been detected in certain breast cancer subtypes and is believed to drive their abnormal proliferation [162]. Novel lipid phosphatases have been shown to be important in regulation of this pathway. Inositol polyphosphate 4-phosphatase type II (INPP4B), is a tumor suppressor gene implicated in many cancers including: breast, ovarian and prostate cancers [163].

\section{mTORC1 and mTORC2 Complexes}

The S/T mTOR kinase is a critical component of two complexes, mTORC1 and mTORC2. In the mTORC1 complex, mTOR complexes with Raptor (Regulatory associated protein of mTOR) adaptor protein, DEP domain containing mTOR-interacting protein (DEPTOR) and mLST8, a member of the Lethal-with-Sec-Thirteen gene family, first identified in yeast, FK506 Binding Protein 38 (FKBP38) and proline-rich Akt substrate $40 \mathrm{kDa}$ protein (PRAS40) [150,164,165]. DEPTOR may be a tumor suppressor gene as decreased expression of DEPTOR results in increased mTORC1 activity [166]. mTORC2 can function as the elusive PDK-2 which phosphorylates Akt-1 on S473 in response to growth factor stimulation [167].

\section{LKB1/AMPK Network Interactions with GSK-3 and PI3K/Akt/mTORC1 Pathway.}

The LKB1/AMP activated protein kinase (LMPK) pathway is a key pathway initially investigated in metabolic diseases such as diabetes. However, the LMPK pathway is now recognized to play important roles in cancer and other diseases [165]. The LKB1/AMPK pathway can be stimulated by the commonly prescribed drugs, such as N,N-dimethylimidodicarbonimidic diamide (metformin) and 5-aminoimidazole-4-carboxamide $1-\beta$-D-ribofuranoside (AICAR). AICAR is used to prevent cardiac ischemic injury and is also used in diabetes care. Activation of LKB1/AMPK in various tumor types results in cell cycle arrest, caspase-dependent apoptosis or autophagy in various tumors. Metformin inhibits mTORC1-controlled protein translation. Many of the targeted proteins are important in the growth of malignant cells. The translation of these proteins is not as well inhibited with allosteric mTORC1 inhibitors, such as rapamycin and its derivatives. Recently it was shown that metformin also targets the cancer initiating cells (CICs), the critical target for cancer eradication. Thus the LKB1/AMPK pathway is critically involved in regulating diseases such as diabetes as well as the proliferation and survival of malignant cells. Drugs targeting and activating LKB1/AMPK maybe a novel, less toxic and cost effective treatment option for certain malignancies [168,169].

The ability of metformin to suppress the 
proliferation of T-acute lymphoblastic leukemias (T-ALL) cell lines and primary T-ALL patient samples displaying mTORC1 activation was examined. Metformin induced autophagy and apoptosis and inhibited proliferation. The effects of metformin on control CD4+ T-lymphocytes were examined. Metformin was much less toxic against CD4+ T-lymphocytes from healthy donors than against either the T-ALL cell lines or primary patient cells. These studies documented the dephosphorylation of downstream targets of mTORC1. In addition, inhibition of mRNA translation in metformin-treated T-ALL cells was observed. In contrast, a similar inhibition of translation was not observed after rapamycin treatment. Importantly in primary patient samples, metformin targeted the side population of T-ALL cell lines as well as a putative leukemia initiating cell (LIC) subpopulation (CD34+, CD7-, CD4-). Metformin exhibited anti-leukemic activity, which supports further development of LKB1/ AMPK pathway activators as potential clinical candidates for T-ALL therapy [170]. AMPK is also important in BCR-ABL-induced chronic myeloid leukemia (CML) and AMPK pathway activators may prove useful as combination drug therapy (with BCR-ABL inhibitors) for this disease [171]. AMPK can also be activated by rapamycin [172].

$L K B 1$ is an important tumor suppressor and gatekeeper mutations of $L K B 1$ cause the rare Peutz-Jeghers Syndrome (PJS) which is a cancer-prone syndrome [173]. LKB1 is a critical regulator of cell polarity and energy/ metabolism control and exerts it vast effects via diverse effectors $[174,175]$. AMPK is considered a metabolic gatekeeper important in many diseases including diabetes, cancer and neurologic disorders. Inhibiting mTORC1 activity by drugs such as metformin and other drugs (including rapamycin) may not only aid in the treatment of diabetics, but also improve cancer therapies and increase longevity [176-179].

The plant natural product berberine has recently been shown to inhibit the growth of drug-resistant breast cancer cells whereas the parental drug sensitive line was not as growth inhibited. Berberine may also target LKB1/ AMPK. Cells overexpressing neutrophil gelatinaseassociated lipocalin (NGAL) were more sensitive to berberine than parental cells which did not over express NGAL [180].

\section{Wnt Absent}
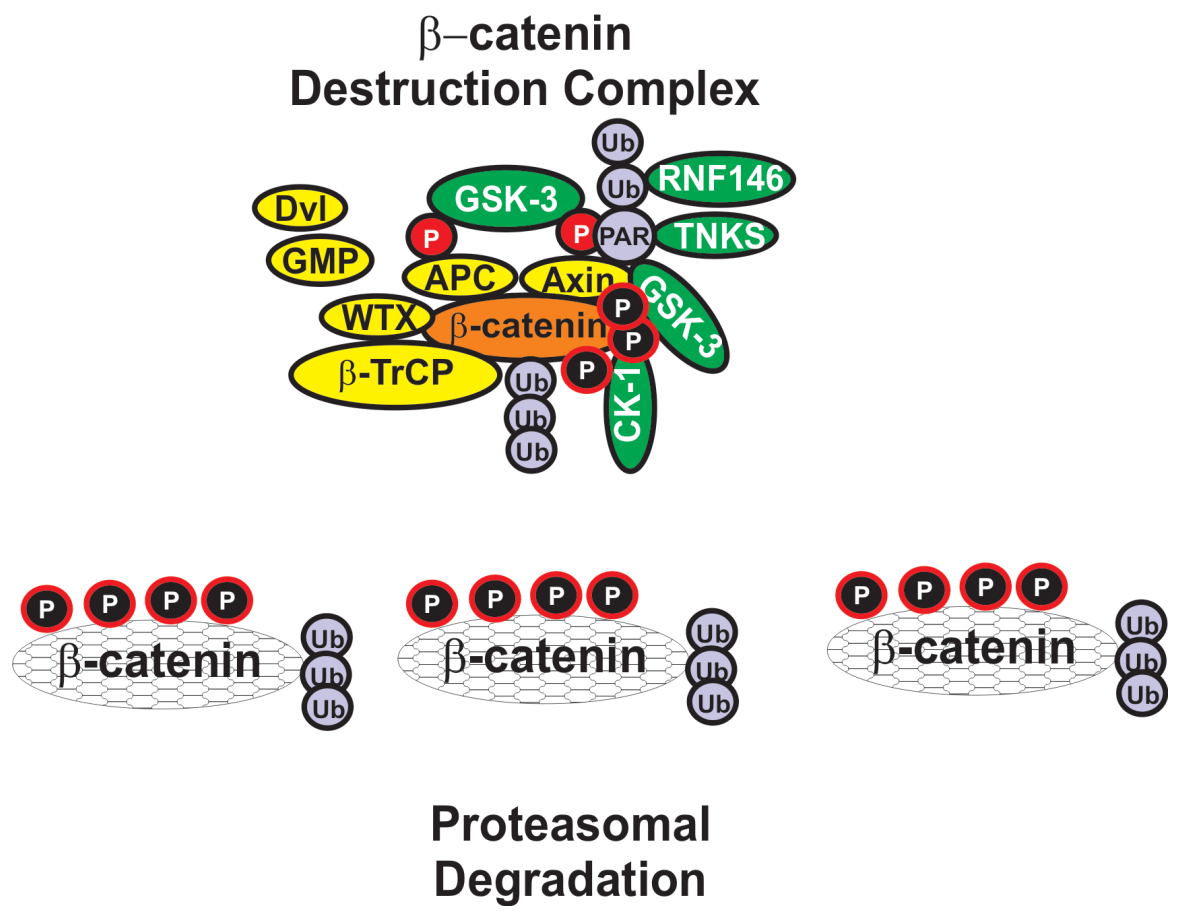

Figure 5: Formation of beta-catenin Destruction Complex. When Wnt is absent, beta-catenin is targeted for proteasomal degradation. GMP, indicated in a yellow oval, is displaced from GSK-3 and GSK-3 is able to phosphorylate beta-catenin which results in its ubiquitination by the beta-TrCP complex which is indicated in a yellow oval. Ubiquitination is indicated by Ub in purple circles. Axin is also poly-ADP-ribosylated (PAR) by tankyrase (TNKS) in a green oval with white letters. PAR is indicated in a purple circle which subsequently leads to the proteasomal degradation of Axin. Axin is also ubiquitinated by RNF146 RING-type ubiquitin E3 ligase (RNF146) is indicated by a green ovals with white letters. 


\section{Regulation of mTORC by GSK-3, TSC1/TSC2 and Other Molecules.}

The activity of the mTORC1 complex is regulated by many different molecules. Akt can suppress tuberous sclerosis 2 (TSC2 or tuberin) function by phosphorylation [181]. TSC2 is a GTPase activating protein (GAP). TSC2 functions in association with TSC1 (hamartin) to regulate mTORC1 activity. TSC1/TSC2 inactivate the small G protein Ras homolog enriched in brain (Rheb) [182]. TSC2 phosphorylation by Akt represses GAP activity of the TSC1/TSC2 complex, allowing Rheb to accumulate in a GTP-bound state. Rheb-GTP then activates the protein kinase activity of mTOR present in the mTORC1 complex.

GSK-3 plays key roles in this regulatory circuit.

The TSC1/TSC2 complex can negatively-regulate proliferation through mTORC1 inhibition and GSK-3beta activation. GSK-3 can also interact with TSC1/TSC2 by phosphorylating TSC2 and activating it [183]. This regulatory loop would result in suppression of mTORC1 activity.

Akt also phosphorylates the proline-rich Akt substrate of $40 \mathrm{kDa}$ (PRAS40), another inhibitor of mTORC1. When PRAS40 is phosphorylated by Akt, it can not suppress mTORC1 signalling [154,154,165,169,183185]. Thus, this is another mechanism by which Akt activates mTORC1. To complicate matters, PRAS40 is a substrate of mTORC1 itself, and mTORC1-mediated phosphorylation of PRAS40 prevents inhibition of additional mTORC1 signaling. The Ras/Raf/MEK/ERK signaling pathway also regulates mTORC1. TSC2 is phosphorylated by both ERK and p $90^{\text {Rsk-1 }}$. When TSC2 is phosphorylated by either ERK or p90 $0^{\text {Rsk-1 }}$, its inhibitory function is suppressed [183-185]. Moreover, inhibition of mTORC1 can result in ERK1/2 activation, through p70S6K/PI3K/Ras/Raf/MEK [186].

The mechanism(s) by which Rheb-GTP activates mTORC1 are not fully elucidated. However for Rheb to activate mTORC1, Rheb must be farnesylated and farnesylation can be suppressed by farnesyl transferase (FT) inhibitors. Rheb-GTP may relieve the inhibitory function of FK506-binding protein 8 (FKBP38) on mTOR, thus leading to mTORC1 activation [182].

mTORC1 also inhibits Akt via a negative feedback loop which involves p70S6K and potentially other molecules [187]. p70S6K can exert negative effects on insulin receptor substrate-1 (IRS-1) $[154,154,165,169,183$ 185]. p70S6K can phosphorylate IRS-1 on S312 and/ or S636/S639. This results in the targeting of IRS-1 to the proteasome where it is degraded. Hence PI3K/ Akt signaling downstream of IRS-1 is downregulated when p70S6K is active. Rapamycin blocks mTORC1 and p70S6K activation, thus this loop is broken upon rapamycin was added and Akt is activated.

GSK-3 can regulate this pathway by phosphorylation of S371 on p70S6K $[61,62,65,186,187]$. GSK-3 interacts with mTORC1 to regulate p70S6K activity $[61,62]$. GSK3 beta can have negative effects on p70S6K activity [188]. GSK-3 can phosphorylate TSC2 which results in inhibition of mTORC1 and prevents the phosphorylation of p70S6K at T389 $[189,190]$. Little is known about the interactions of GSK-3 and mTORC2 in oncogenesis. mTORC2 stabilizes cyclin D1 through prevention of GSK3- dependent and FBX4-mediated cyclin D1 degradation [190] Thursday

\section{Involvement of GSK-3 in Hematopoietic Stem Cell (HSC) Homeostasis}

To maintain a balanced number of self-renewing cells or to generate the required lineage-differentiated progeny cells necessary to fulfill the loss of mature blood cells, normal HSCs exit quiescence under the appropriate circumstances. GSK-3 plays key roles in HSC homeostasis by regulating the quiescent HSC pool [91]. Depletion of functional GSK-3 activity in bone marrow (BM) transiently expanded HSC in a beta-catenindependent fashion, indicating roles for GSK-3 and Wnt/ beta-catenin signaling in homeostasis. Depletion of GSK3 activity in the HSC pool resulted in their depletion by activation of mTORC1. Loss of the HSCs in the GSK3-deficient BM could be suppressed by treatment with mTORC1 inhibitors. GSK-3 is a master regulatory switch which controls both Wnt/beta-catenin and mTORC1 signaling which in turn regulates HSC self renewal and lineage commitment respectively. This important study has suggested a potential therapeutic approach to expand HSCs in vivo by using already approved drugs for treatment of other diseases (rapamycin/rapalogs to inhibit mTORC1 and lithium to inhibit GSK-3).

As stated previously, GSK-3 phosphorylates TSC2 which in turn inhibits Rheb and mTORC1 activity. The PTEN phosphatase is upstream of GSK-3. PTEN negatively regulates Akt activity by de-phosphorylating phosphatidylinositol $(3,4,5)$-trisphosphate (PIP3) which Akt requires for membrane localization. PTEN and TSC1 knock-out mice have similar hematopoietic phenotypes. Increases in HSC were transiently observed which were followed by HSC depetion and lineage commitment $[192,193]$. The authors suggested that there were additional tumor suppressors which were induced in $P T E N$-mutant mice indicating the complicated interacting genetic factors between PTEN loss and mTOR activation [194]. Knock-down of GSK-3alpha and GSK-3beta induced a similar HSC phenotype as observed in PTEN/- and TSC-1-/- mice as the HSCs initially increased and then they were progressively depleted [195]. Thus GSK3 plays critical roles in HSC homeostasis and regulating the decision between self-renewal and differentiation. These pathways often have competing functions in HSC self renewal and differentiation. Wnt signaling can induce mTORC 1 activity by preventing the inhibitory effects that 
GSK-3 has on mTORC activity. Thus there is a division of the canonical Wnt pathway with Wnt or GSK-3 inducing opposing signal pathways. Wnt and GSK-3 can activate potentially opposing processes (HSC renewal vs. differentiation). Other factors and molecules may also be discovered that may modify the balance and modify HSC homeostasis.

Nutrient-sensing pathways interact to regulate HSC homeostasis. HSCs reside in the BM in a nutrient and oxygen-deprived niche. Both the mTORC1 and LKB1 pathways are important nutrient-sensing pathways. Dysregulation of these pathways alters HSC homeostasis. Increased mTORC1 activity or decreased LKB1 activity [193,196-199] stimulates the proliferation of committed progenitors and decreases HSCs. Low nutrient availability is a critical component which controls HSC homeostasis.

Suppression of this pathway by rapamycin combined with activation of Wnt/beta-catenin pathway by GSK-3 inhibitors permitted ex vivo maintenance of human and mouse HSCs in the absence of exogenous cytokines. These studies demonstrated that two drugs (GSK inhibitor CHIR99021 and the mTOR blocker rapamycin) increased the number of long-term HSC in vivo [200]. Thus GSK-3 plays roles in HSC homeostasis as a suppressor of Wnt/ beta catenin self-renewal pathway and also as a suppressor of the mTORC1 pathway which would normally promote lineage commitment and stem-cell depletion. Inhibition of GSK-3 activated self renewal while suppression of mTORC1 prevented HSC depetion allowing the generation of long term HSC (but not the proportion) in vivo. This approach may also prove useful for both hematopoietic recovery and immune reconstitution in umbilical cord blood transplantation.

The promyelocytic leukemia (PML)-peroxisome proliferator-activated receptor-delta (PPAR-delta)fatty-acid oxidation (FAO) pathway is another pathway which is important in HSC maintenance [201]. GSK-3 regulates this pathway. PPARs are regulated by GSK3 phosphorylation [202]. Loss of HSC maintenance can occur after suppression of PPAR-delta or inhibition of mitochondria FAO. Improved HSC maintenance was observed after treatment with PPAR-delta agonists. PML regulates PPAR signaling and FAO which have important roles in HSC maintenance [201]. The asymmetric division of HSCs is controlled by this pathway. Thus the PPARFAO pathway is a metabolic regulatory switch for the control of HSC fate. PPARs are important transcription factors that regulate nutrient sensing and metabolic pathways including FAO and fatty acid transport. These studies have important therapeutic implications as small

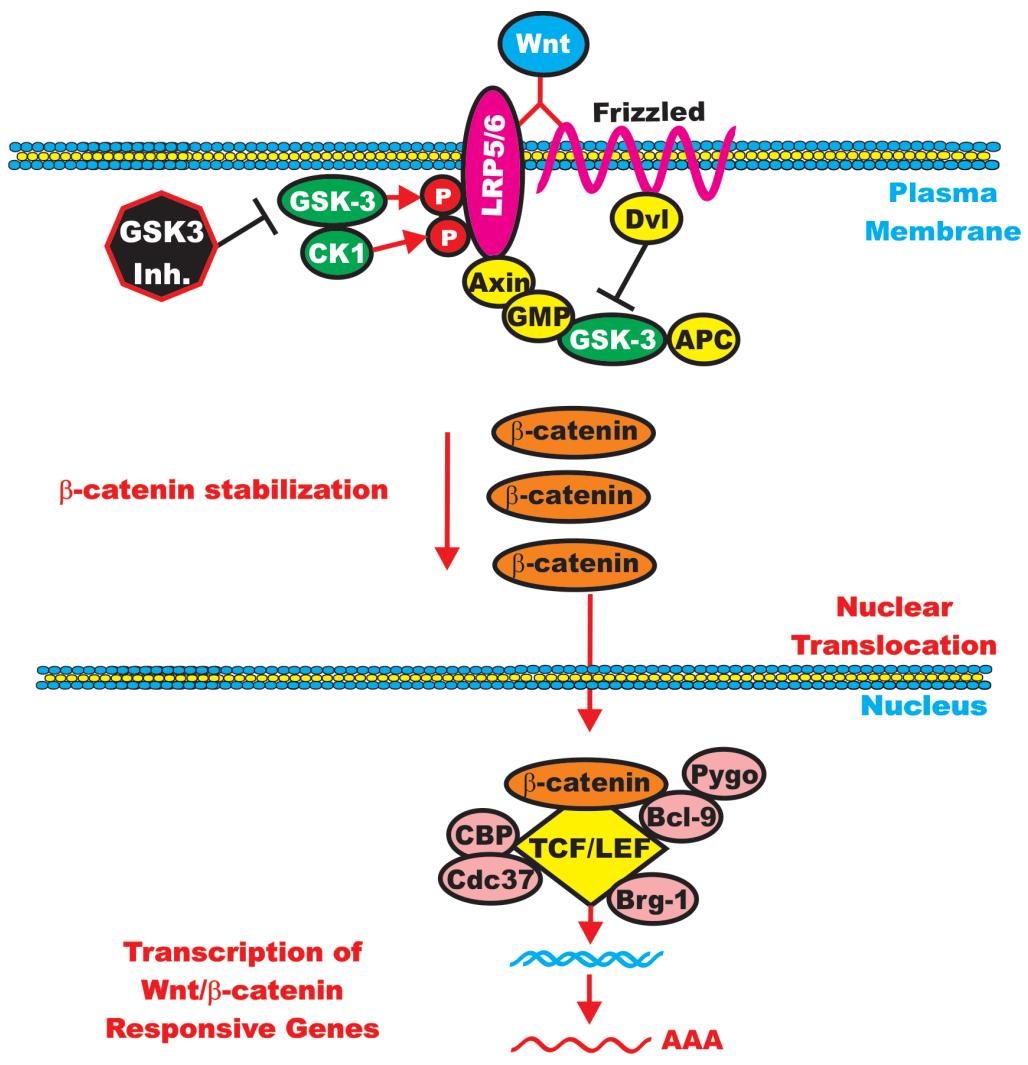

Figure 6: GSK-3 can Enhance Wnt/beta-catenin signaling. GSK-3 and CK-1 can phosphorylate and stabilize LRP5/6 which promotes beta-catenin signaling. GSK-3 inhibitors could inhibit beta-catenin-mediated gene expression. GSK-3 inhibitors are indicated by a black octagon with white lettering. 
molecule PPAR activators and inhibitors have been developed and evaluated for the treatment of obesity and metabolic disorders [203,204].

The $P M L$ gene is a tumor suppressor gene originally cloned from the break point of the $\mathrm{t}(15 ; 17)$ chromosomal translocation present in PML. PML has an important role in regulating the maintenance of HSCs and LIC quiescence. Suppressing the activity of PML eliminated certain LICs [205]. PML-deficient CML-LICs became exhausted over time and lost their ability to generate CML in transplanted mice. PML also acted as a negative regulator of mTORC1 in a mouse CML model [206-207]. Repressing or balancing mTORC1 activity is important in HSC maintenance. Elevated mTORC1 activity adversely affected LIC maintenance while the mTORC1 blocker rapamycin prevented the exhaustion of $\mathrm{Pml}^{-/}$LICs. PML is targeted for degradation by arsenic trioxide. Arsenic trioxide treatment of murine CML models decreased PML expression and prevented maintenance of CML-LIC quiescence.

GSK-3 inhibition permitted mouse embryonic stem cells (ESC) to maintain pluripotency. ESCs prepared from mice lacking GSK-3alpha and GSK-3beta retained some markers of pluripotency even when they were cultured under differentiation-inducing conditions [208-209].

GSK-3 and mTORC1 may also regulate $\mathrm{T}$ cell memory. Importantly inhibition of GSK-3, mTORC1 or both may augment the number and competence of CD8+ memory T cells [210-212].

\section{Involvement of GSK-3 and Wnt/beta-catenin Signaling.}

Essentially there are two Wnt signaling pathways, a canonical Wnt signaling pathway which is beta-catenindependent and a non-canonical Wnt signaling pathway which is beta-catenin-independent. Beta-catenin can play multiple roles in cell physiology. Different pools of beta-catenin likely exist at various subcellular locations. For example one pool of beta-catenin is associated with cadherins at the cell-cell junctions while another pool of beta-catenin is "free" and localized in the cytosol and nucleus where it can play important roles in regulating gene expression. "Free" beta-catenin exists at a low level and is regulated by rapid turn-over. GSK-3 is critical in regulating the turnover of beta-catenin. An overview of the interactions between GSK-3 and the Wnt/beta-catenin pathway is presented in Figure 5.

The Wnt gene family is comprised of approximately nineteen genes in mammals. Wnt genes are found in multicellular animals but not in single-cell organisms suggesting that the Wnt genes played essential roles in the evolution of multicellular organisms [213]. When Wnt binds it's receptor, a conformation change of the receptor occurs resulting in the phosphorylation of target proteins. Wnt binds a member of the Frizzled (Fz) family which is comprised of approximately 10 family members. $\mathrm{Fz}$ proteins are membrane bound receptors which are G-protein coupled receptors (GPCRs). The low density lipoprotein receptor (LDR) related proteins 5/6 (LRP5 or LRP6) are transmembrane proteins which are co-receptors for Wnt. Additional proteins can interact with Wnt to transduce various signals, these include receptor tyrosine kinases (RTKs), such as receptor-tyrosine-kinase-like orphan receptor 1 (ROR1) and ROR2 as well as the RTKlike proteins [214].

The GSK-3 Drosophila homologue is zeste-white 3 , a negative regulator of wingless (Wg) signaling which is critical for normal development. Wnt is the vertebrate homologue of $\mathrm{Wg}$ and the Wnts are responsive for embryonic patterning as well as many other processes and their dysregulation can result in cancer [215]. Wnt signaling is complex as at least 19 different Wnts exist in mammals and depending on the cellular context, different Wnts can induce or suppress critical aspects of proliferation. Activation of the canonical Wnt/beta-catenin pathway results in the induction of T cell factor/lymphoid enhancer factor-1 (TCF/LEF)-responsive genes. betacatenin serves as a transactivator which binds to $\mathrm{TCF} /$ LEFs which are bound to specific gene targets in the DNA.

GSK-3 normally inhibits this pathway as in the absence of Wnt ligands; GSK-3 phosphorylates the amino terminals domain of beta-catenin which targets it for ubiquitination and proteasomal degradation. However, when Wnt ligands are present, GSK-3 is inactivated. The disheveled (Dvl) phosphoprotein is required to transduce a signal from Wnt that results in the inactivation of GSK3beta [216]. As a result, beta-catenin is dephosphorylated and accumulates in the cytoplasm and translocates to the nucleus where it associates with TCF/LEFs to become a transcriptional co-activator [29].

\section{Regulation of beta-Catenin Activity by GSK-3}

In the absence of stimulation, CK1 phosphorylates beta-catenin at $\mathrm{S} 45$ which primes beta-catenin for subsequent phosphorylation by GSK-3 at S41, S37 and S33 [29,143,217-221]. These phosphorylation events target beta-catenin for ubiquitination and proteasomal degradation [29]. A blow up of the Wnt/beta-catenin and beta catenin destruction complex is presented in Figure 5.

When Wnt ligand is present, it binds Fz, which signals through Dvl to suppress beta-catenin phosphorylation. beta-catenin is then able to complex with LEF/TCF and induces the transcription of genes. When beta-catenin is mutated at certain nucleotides it can act as an oncogene, as the beta-catenin proteins can not be phosphorylated by GSK-3 or CKI (depending on the residue). Other regulatory proteins are also involved in controlling the activity of the Wnt/beta-catenin complex. In many cases, they may be either oncogenes or tumor 
suppressor genes. GSK-3-binding protein (GBP), also known as, frequently rearranged in advanced T-cell lymphomas (FRAT), may regulate the binding of GSK3 to Axin. Diversin (Div) is an ankyrin rich protein that interacts with both Dvl and Axin to promote Wnt signaling. The beta-catenin destruction complex consists of: beta-catenin, axin/conductin, adenomatous polyposis coli (APC), CK1, GSK-3 and GBP. APC is a tumorsuppressor gene and an essential component of the betacatenin complex which controls cytoplasmic beta-catenin levels. Mutations at APC are detected in certain cancers such as colo-rectal cancer (CRC). Mutations at APC occur early in CRC and result in increased beta-catenin levels which lead to the expression of Wnt/beta-catenin responsive genes. The Axin and related conductin (Axil) proteins contain multiple protein:protein interaction domains. The Axin/Axil proteins interact with APC and form key components of the beta-catenin destruction complex. Axin and APC are both phosphorylated by GSK-3. Phosphorylation of Axin by GSK-3 increases it stability as well as its ability to bind to beta-catenin [222225]. CKI is a priming kinase by phosphorylating Axin, Dvl and APC. Once these proteins are phosphorylated by CK1, GSK-3 then phosphorylates them. The Div protein can recruit $\mathrm{CKI}$ to the beta-catenin destruction complex [226].

GBP plays key important roles in the interactions between GSK-3 and other proteins. The binding sites for Axin and GBP on GSK-3 are overlapping. When GSK-3 is bound to GBP, GSK-3 cannot bind Axin and thus GSK-3 does not phosphorylate beta-catenin [227,228]. GBP can regulate the nuclear export of GSK-3 [229] and control

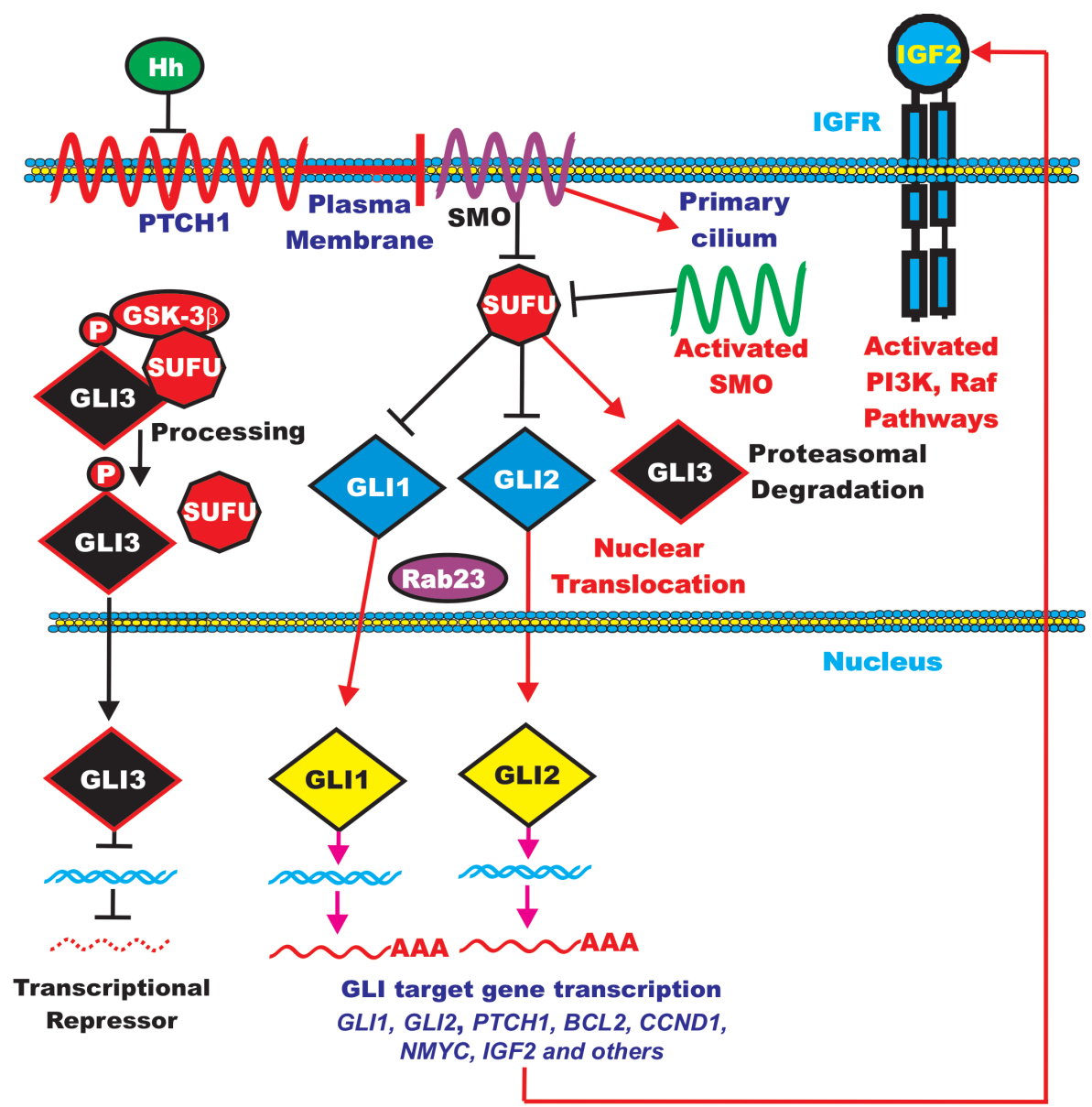

Figure 7: Overview of Hedgehog Signaling Pathway. The Hh pathway normally inhibits the membrane spanning PTCH1 GPCR receptor which is indicated by a squiggly red line crossing the membrane 14 times. PTCH1 normally inhibits SMO which is indicated by a purple squiggly line which crosses the membrane 7 times. SMO is then activated in the primary cilium and serves to inhibit SUFU which is indicated by a red octagon. SUFU normally inhibits the GLI1 and GLI2 transcriptions factors which are indicated in blue diamonds. The Rab23 GTPase may aid in the nuclear translocation of the transcription factors and is indicated by a purple oval. In contrast, GLI3 is activated by SUFU and may serve as a transcriptional repressor and is regulated by GSK-3. It is indicated in a black diamond. One of the genes that are regulated by GLI signaling is $I G F 2$. Dysregulation of Hh signaling pathway occurs in certain cancers. Resistance to Hh pathway inhibitors may result from mutations in the pathways which lead to increased pathway expression and autocrine IGF2 expression. This figure is presented to give the reader an idea of the negative regulation of the Hh pathway by various components 


\section{Table 1: GSK-3 Inhibitors}

\begin{tabular}{|c|c|c|c|c|}
\hline & Inhibition & Inhibition & & \\
\hline Inhibitor Name & GSK-3 $\alpha$ & GSK-3 $\beta$ & Structure & Ref/Clinical Trials \\
\hline SB216763 & + & + & & {$[308,309]$} \\
\hline TWS119 & & + & & {$[312]$} \\
\hline SB415286 & + & + & & {$[310,311]$} \\
\hline $\begin{array}{l}\text { Tideglusib } \\
\text { (NP031112, NP-12) }\end{array}$ & & + & & $\begin{array}{l}{[284,314]} \\
\text { NCT00948259 } \\
\text { NCT01049399 }\end{array}$ \\
\hline AR-A014418 & & + & & [301] \\
\hline $\begin{array}{l}\text { TDZD-8 } \\
\text { (NP01139) }\end{array}$ & & + & & [302] \\
\hline LY2090314 & + & + & & $\begin{array}{l}{[307]} \\
\text { NCT01632306 } \\
\text { NCT01287520 } \\
\text { NCT01214603 }\end{array}$ \\
\hline
\end{tabular}

Clinical Trials

Phase I/II: LY2090314 works in combination with different chemotherapies in treating participants with metastatic pancreatic cancer ClinicalTrials.gov Identifier: NCT01632306 Recruiting

Phase I: LY2090314 in combination with pemetrexed and carboplatin in patients with advanced/metastatic cancer ClinicalTrials.gov Identifier: NCT01287520 Completed

Phase 2 study of intravenous LY2090314 in participants with acute leukemia ClinicalTrials.gov Identifier: NCT01214603 Completed 
the accessibility of nuclear and cytoplasmic substrates to GSK-3

Dvl attaches to the cytoplasmic portion of Fz. Wnt/ $\mathrm{Fz}$ then associates with the Wnt-coreceptor LRP5 or LRP6. CKI phosphorylates and primes LRP6 on T1479. GSK-3beta then plays a positive role in Wnt signaling by phosphorylating LRP6 on S1490. These events are required for Axin to bind to the complex which results in beta-catenin stabilization. beta-catenin can then enter the nucleus and effect gene transcription [230-235]. Figure 6 presents a diagram of the positive effects which CKI and GSK-3 exert on Wnt/beta-catenin signaling. Targeting GSK-3 may be effective in suppressing the growth of certain cancers.

Axin attaches to the cytoplasmic portion of LRP6. This complex sequesters beta-catenin away from the betacatenin destruction complex and suppresses the ability of GSK-3beta to phosphorylate beta-catenin. If Wnt signaling is turned on, GSK-3-mediated phosphorylation of S33, S37 and T41 on beta-catenin is suppressed and beta-catenin is stabilized.

GSK-3 has two roles in regulation of Wnt/betacatenin signaling. Phosphorylation of LRP5/6 stabilizes Axin while phosphorylation of beta-catenin targets it for proteasomal degradation. As stated previously, there may be multiple pools of GSK-3 in cells; one linked with Axin and is resistant to phosphorylation by Akt. Another pool of GSK-3 is regulated by Akt and when it is phosphorylated by Akt it is destabilized and degraded [230]. Introduction of constructs encoding activated Akt did not activate betacatenin signaling in the examined model system in terms of changes in levels of LEF1-dependent transcription [231]. Wnt may induce GSK-3 and Axin translocation to the plasma membrane. These translocations may be dependent upon interactions with Fz and Dvl [232-234]. Axin is required for GSK-3 to phosphorylate LRP5/6. Wnt signaling induces the association of CKI with LRP5/6. This association may also be involved in Wnt-induced Axin recruitment [290].

CKI phosphorylates beta-catenin on S45 when Wnt signaling is extinguished. GSK-3beta can then phosphorylate beta-catenin on S33, S37 and T41. The Axin/GSK-3/CK1/APC complex induces the degradation of beta-catenin. This occurs via ubiquitination by the SKP1/cullin1-F-box E3 ligase (beta-TrCP) complex in the $26 \mathrm{~S}$ proteasome. The tumor suppressor APC interacts with both GSK-3 and beta-catenin. Axin serves as the scaffold of the destruction complex. APC binds directly to Axin. Axin is phosphorylated by CKI and then GSK-3 [291]. The affinity of beta-TrCP for beta-catenin is normally low. The Wilms tumor suppressor (WTX) protein increases the affinity of beta-TrCP for beta-catenin [237]. A complex is formed consisting of and APC, Axin, beta-catenin, beta-TrCP and WTX, which promotes beta-catenin ubiquitination and subsequent proteasomal degradation.

Axin, Apc and WTX are tumor-suppressor proteins.
APC increases the activity of GSK-3 [238]. GSK-3 phosphorylates conserved serines present in the PPPSP motif found in many Wnt signaling components such as beta-catenin, Axin, and APC.

\section{GSK-3 and beta-Catenin Signaling and Hepatocarcinogenesis}

The dysregulation of GSK-3beta phosphorylation and inhibition of GSK-3beta activity has been shown to be involved in hepatocarcinogenesis [239]. In a recent study performed on $80 \mathrm{HCC}$ patients, the expression of GSK-3beta protein in HCC tissues was found to be significantly lower than that in normal liver tissues and pericancerous tissues [240]. In addition, low expression of GSK-3beta was correlated significantly with advanced clinicopathological characteristics and poor prognosis of HCC patients. GSK-3beta expression was also correlated with vascular invasion, histological grade, TNM classification and therefore could be involved in process of HCC metastasis [241].

In a different study, it was reported that some HCC cells expressed high basal levels of S9-phosphorylated GSK-3beta [242]. As a result of the sustained phosphorylation of GSK-3beta, beta-catenin was stabilized and contributed to hepatic transformation.

Infection with either $\mathrm{HBV}$ or $\mathrm{HCV}$ are well known risk factors for HCC. $\mathrm{HBx}$ is one of the four proteins encoded by the HBV genome. Several studies have reported its involvement in liver carcinogenesis. Expression of $\mathrm{HBx}$ in hepatocytes activates the Ras/Raf/ MEK/ERK signaling cascade. Interestingly, cross-talk between the Ras/Raf/MEK/ERK and Wnt/beta-catenin signaling has been observed in hepatoma cells [243]. $\mathrm{HBx}$ activates ERK and as consequence it associates and primes GSK-3beta for its inactivation. In particular, activated ERK phosphorylated GSK-3beta at T43, which primers GSK-3beta for its subsequent phosphorylation at S9 by $\mathrm{p} 90^{\text {Rsk }}$, resulting in inactivation of GSK-3beta. In turn, inactivation of GSK-3beta promoted beta-catenin stabilization and signaling [243]. In other scenarios, ERK can collaborate with GSK-3 in the phosphorylation of paxillin and regulate cytoskeletal rearrangement [244].

Among the $\mathrm{HCV}$ encoded proteins, the core protein has been reported to contribute to HCC carcinogenesis. Interestingly, $\mathrm{HCV}$ core protein increases and stabilizes beta-catenin levels in hepatoma cells through inactivation of GSK-3beta by phosphorylation at S9. This results in stabilization of beta-catenin and enhancement of canonical Wnt/beta-catenin signaling activity. Downstream betacatenin target genes, such as $c-M y c$, cyclin D1, WNT1inducible-signaling pathway protein 2 (WISP2) and connective tissue growth factor $(C T G F)$ are expressed at higher levels [245].

GSK-3beta/beta-catenin signaling plays roles in the 
Sirtuin 2 (SIRT2)-mediated transformation in HCC [246]. SIRT2 is a member of sirtuin family, which is upregulated in about $50 \%$ of HCC patients. Increased SIRT2 expression is correlated with shorter overall survival [246]. The sirtuins have been associated with oxidative stress and aging [247]. The authors demonstrated that SIRT2 regulated activation of Akt by its deacetylation [246]. Subsequently Akt phosphorylated and inactivated GSK-3beta. The beta-catenin-signaling cascade is enhanced and promoted EMT and cell migration of HCC cells. Together these results suggested that GSK-3beta is probably a tumor suppressor gene in $\mathrm{HCC}$, and the loss of GSK-3beta expression and/or activity may contribute to development of HCC.

However, the roles of GSK-3beta in HCC remain controversial and several studies indicate that GSK-3beta is a potential therapeutic target for a broad spectrum of cancer types [248-253] including HCC [254.255].

Inhibition of GSK-3beta activity with the GSK3beta inhibitors SB-216763 and AR-A014418 controled cancer cell survival and proliferation, in a manner unrelated to Wnt/beta-catenin signaling and Akt activation, through decreasing telomerase reverse transcriptase (hTERT) expression and telomerase activity [256]. GSK-3beta inhibitors, lithium and SB-415286, have been also reported to overcome the inherent resistance of human hepatoma cells towards TRAIL-induced apoptosis. The inhibitors exerted their anticancer activity through a complex mechanism which involved the promotion of apoptotic signals (caspase- 8 , caspase- 3 and TP53 activation) and of protective signals (JNK activation) [257].

\section{Wnt/GSK-3 Regulation of mTORC1 Pathway.}

Wnt signaling can regulate the mTORC1 pathway via GSK-3 by a beta-catenin-independent mechanism [189]. GSK-3 can phosphorylate TSC2 after it has been phosphorylated (priming phosphorylation) by AMPK. This would lead to inhibition of mTORC1. In contrast, Wnt signaling suppresses GSK-3-mediated phosphorylation of TSC2 and the mTORC1 pathway is activated. Inhibition of Wnt-mediated activation of mTORC1 by rapamycin suppressed Wnt-mediated cellular proliferation. Activation of AMPK by metformin suppressed Wnt-mediated cellular proliferation [192]. In addition to GSK-3, Dickkopfrelated protein 1 (DKK1), Dvl and Axin also modulate the effects Wnt has on regulation of $\mathrm{mTORC1}$ and cellular proliferation.

\section{Wnt/GSK-3 Signaling in the Regulation of SMAD1.}

Mothers against decapentaplegic homolog 1 (SMAD1) is a mediator of the transforming growth factorbeta (TGF-beta)/bone morphogenetic protein (BMP) superfamily of ligands. Both MAPK and GSK-3 were determined to phosphorylate SMAD1 on its linker region which resulted in its polyubiquitinylation and transport to the centrosome where it was degraded by proteasomes. The priming phosphorylation mediated by MAPKs (ERK, JNK, p38 $8^{\text {MAPK}}$ ) to phosphorylate SMAD1 was most likely required for GSK-3 activity [258]. Wnt signaling decreased GSK-3 phosphorylation of SMAD1. Thus, the Wnt/GSK3/SMAD1 pathway plays an important role in embryonic pattern formation.

\section{Overview of Hedgehog Pathway.}

The hedgehog (Hh) pathway is an important developmental pathway that controls segmental pattern formation. There are three $\mathrm{Hh}$ genes, desert hedgehog $(\mathrm{DHH})$, Indian hedgehog (IHH) and sonic hedgehog (SHH). These hedgehogs function as ligands for the 12pass transmembrane receptor patched (PTCH1) which controls many developmental signaling events [259]. Hhs can function in some cases as mitogens, while in other cases they promote differentiation. An overview of the Hh pathway is presented in Figure 7.

Hh ligands bind their receptor PTCH1. This causes its internalization and degradation and release of Smoothened (SMO), a GPCR. SMO then promotes the dissociation of a suppressor of fused (SUFU)glioma-associated oncogene homologue (GLI) complex. This allows the transcription factors GLI1 and GLI2 to translocate to the nucleus and ultimately induce the transcription of certain genes. In contrast, GLI3 is degraded during this process as it normally functions as a repressor.

GLI3 can be phosphorylated by PKA, GSK-3 and CK1 which results in GLI3 becoming a transcriptional repressor. Activated GLI proteins stimulate the transcription of Hh target genes, including: GLI1, GLI2, PTCH1, CCND1, IGF2, MYC, and BCL2. IGF-2 has been determined in some studies to subsequently induce the PI3K/PTEN/Akt/mTOR pathway and influence proliferation and survival as well as inhibit GSK-3beta [260].

The Hh pathway interacts with other signaling pathway regulators such as BMPs, parthyroid hormone and retinoids. The Hh pathway is aberrantly regulated in certain tumors. There is substantial interest in isolating inhibitors which can suppress its activity in various cancers and other disorders.

\section{GSK-3 Regulation of Hh Signaling.}

The Hh pathway is regulated by GSK-3 [261]. The Hh pathway is inhibited when GSK-3 is suppressed. GSK-3beta is a specific binding partner of SUFU, a negative regulator of the Hh pathway. SUFU suppresses 
GLI activity by sequestering GLI in the cytoplasm [262]. When GSK-3 phosphorylates SUFU, Hh pathway activity is increased. Hh pathway activation stimulates GSK-3beta to phosphorylate SUFU which induces the dissociation of SUFU from GLI3. GSK-3beta regulates the $\mathrm{Hh}$ pathway by phosphorylating GLI [263]. The Hh pathway activates the GLI transcription factor by suppressing the function of SUFU. SUFU recruits GSK-3beta into a trimolecular complex of GLI3/SUFU/GSK-3beta. GSK3 beta then phosphorylates GLI3 which results in a SUFU/ GLI3 transcriptional repressor. Shh then dissociates the GLI3/SUFU/GSK-3 beta complex from GLI3 which prevents GLI3 processing and results in GLI3 becoming a transcriptional activator instead of a transcriptional repressor.

\section{Overview of Notch Signaling Pathway.}

Notch signaling is important in many processes including cellular fate decisions [264]. Notch signaling is activated by cell to cell interactions which result in the step wise cleavage of Notch first by a TACE- metalloprotease, and then a gamma-secretase [265-267]. This cleavage results in the release of the Notch intracellular domain (NICD). NICD can then translocate into the nucleus to bind transcription factors such as centromere binding factor (CBF1) which further recruits transcriptional coactivators including MAML1, histone acetyl transferases and cAMP response element-binding protein (CREB)binding protein/p300 [268,269].

\section{GSK-3 and Notch Signaling Pathway}

Notch signaling pathway is regulated by GSK-3. GSK-3beta phosphorylates the NICD. This phosphorylation event up-regulates NICD transcriptional activity by preventing its proteasomal degradation [75]. In contrast to the effects of GSK-3, Akt negatively regulates NICD activity [270]. GSK-3beta phosphorylates domains in the NICD of Notch1 (S/T-P-S/T) which are important for the nuclear localization of NICD [271]. Phosphorylation of these domains by GSK-3beta increased the transcriptional activity of NICD. In contrast, other studies have shown that GSK-3 phosphorylation can decrease Notch1 protein levels and its transcriptional activity [272]. beta-catenin could also modulate the transcriptional activity of Notch1/NICD [273]. Betacatenin levels are usually increased when GSK-3 is suppressed. Other studies have indicated that GSK-3beta phosphorylation of Notch downregulates Notch activity [274]. Some of these differences in the effects of GSK-3 on the phosphorylation of Notch observed in the different studies may be related to the different cell lines utilized or culture conditions. Different culture conditions or cell lines containing different mutated activated oncogenes activated and tumor suppressor genes inactivatedmay affect Notch activity. These studies and others indicate the complex interactions between the GSK-3, Wnt/betacatenin and Notch signaling pathways.

\section{GSK-3 Inhibitors}

One of the first described inhibitors of GSK-3 is lithium [275]. Lithium carbonate has been used to treat mania patients since 1871 . It was approved by the FDA in 1970 and it is currently used to treat many different types of patients with depressive disorders [276]. Early clinical studies indicated that lithium had effects on HSCs and other hematopoietic cells [277-279]. Lithium increased circulating HSCs and peripheral blood counts [280]. In 1996, it was proposed that lithium could mobilize HSCs for BM transplantations [281]. An important consequence of suppression of GSK-3 is stimulation of both the Wnt/beta-catenin and PI3K/PTEN/Akt/mTORC1 pathways. However, GSK-3 has many biological effects [275,282,289-299].

More than 50 GSK-3 inhibitors have been described including: lithium [300], AR-A014418 (beta, $\mathrm{IC}_{50}=104$ nM) [301], AZD1080 (alpha \& beta, orally active, brain permeable, with $\mathrm{K}_{\mathrm{i}} \mathrm{s}$ of $6.9 \mathrm{nM}$ and $31 \mathrm{nM}$ respectively) [302], AZD2858 (alpha \& beta $\mathrm{IC}_{50}$ s of $68 \mathrm{nM}$ ) [303], BIO (alpha \& beta IC50 of $5 \mathrm{nM}$ ) [304], CHIR-99021 (alpha \& beta, $\mathrm{IC}_{50} \mathrm{~s}$ of $10 \mathrm{nM} / 6.7 \mathrm{nM}$ ) [305], CHIR-98014 (alpha \& beta, $\mathrm{IC}_{50}$ of 0.65) [306], LY2090314 (alpha \& beta, $\mathrm{IC}_{50} \mathrm{~S}$ of $1.5 \mathrm{nM}$ and $0.9 \mathrm{nM}$ respectively) [307], SB-216763 (alpha \& beta, $\mathrm{IC}_{50} \mathrm{~s}$ of $34.3 \mathrm{nM}$ ) [308, 309], SB-415286 (alpha \& beta $\mathrm{IC}_{50} \mathrm{~s}$ of $78 \mathrm{nM}$ and $31 \mathrm{nM}$ respectively) [310, 311], TDZD-8 (beta, $\mathrm{IC}_{50}$ of 2 microM [312] and TWS119 (beta, $\mathrm{IC}_{50} \mathrm{~s}$ of $30 \mathrm{nM}$ ) [313]. Most GSK-3 inhibitors are ATP-competitive and do not differentiate between either GSK-3alpha or GSK-3beta [28]. Tideglusib (NP031112) is an irreversible, non ATP-competitive GSK3 beta inhibitor with $\mathrm{IC}_{50}$ of $60 \mathrm{nM}$, which is in clinical trials [284, 314]. Table 1 present a listing of some GSK-3 inhibitors and their structures and references.

\section{Clinical Trials with GSK-3 Inhibitors.}

Lithium carbonate has been in clinical trials with bipolar disorder patients [300]. It is also involved in additional clinical trials for patients with Alzheimer disease (NCT01055392 \& NCT00088387), bipolar disorder (NCT01543724, NCT00870311), spinocerebellar ataxia type 3 (NCT01096082) and Machado Joseph disease. Tideglusib has been in clinical trials for patients with Alzheimer's disease (NCT00948259) and progressive supranuclear palsy (NCT01049399). Divalproex (Valproate semisodium) is used for treatment of patients suffering from bipolar disorder, epilepsy and migraines. Divalproex has been in clinical trials in combination 
with lithium, for patients with Alzheimer's disease (NCT00088387), Valproic acid (VPA) is an anticonvulsant and mood-stabilizing drug which can inhibit GSK-3beta. It has been examined in clinical trials (NCT01548066) to determine whether it will prevent hair loss. It has also been examined in a clinical trial (NCT00385710) to determine if it can aid patients with progressive supranuclear palsy. LY2090314 has been in clinical trials for metastatic pancreatic cancer [NCT01632306], advanced or metastatic cancer in combination with pemetrexed and carboplatin [NCT01287520] and acute leukemia [NCT01214603].

\section{GSK-3 Inhibitors in Pre-Clinical Anti-Cancer Studies}

GSK-3 inhibitors may eventually be used in the treatment of certain cancers. GSK-3 is believed to exert pro-proliferative effects in solid cancers including: CRC, glioblastoma, pancreatic cancer and ovarian cancer and in blood cancers including MM, ALL, AML and CLL. Therefore it may be appropriate to treat these cancers and potentially others with GSK-3 inhibitors [124,284-288]. Treatment of the KG1a, K562 and CMK leukemia cell lines with the GSK-3 inhibitor SB-415286 resulted in GSK-3beta S9 phosphorylation beta-catenin stabilization, cyclin B downregulation, cell growth inhibition, cell cycle arrest at $\mathrm{G}_{2} / \mathrm{M}$ and apoptosis [289]. Blocking the death receptor pathway with an inhibitor of caspase 8 did not neutralize the effects of the GSK-3 inhibitor. The GSK-3 inhibitor treatment resulted in dephosphorylation of Bcl2, downregulation of $\mathrm{Bcl}-\mathrm{X}_{\mathrm{L}}$ and led to the depolarization of the mitochondrial membrane potential. The role of stabilized beta-catenin induced by the treatment of the leukemia cells with the GSK-3 inhibitor in the induction of apoptosis of these cells is not clear. The GSK-3 inhibitors SB-415286 and lithium as well as arsenic trioxide inactivated GSK-3beta in AML (APL) cells by inducing the phosphorylation of S9 on GSK-3beta [290]. However, in other cancer types such as breast cancer and medulloblastoma, increased GSK-3 expression is associated with the induction of apoptosis [291,292]. It remains controversial as to whether suppressing GSK3 activity with small molecule inhibitors will inhibit or promote cancer growth.

$1 \mathrm{i}$ is a selective ATP competitive inhibitor of GSK3. 6-bromoindirubin-3-oxime (BIO) and TWS119 are also GSK-3 inhibitors. BIO inhibited GSK-3 and activated Wnt/beta catenin signaling, thereby maintaining the pluripotency of human and mouse ESCs [208]. Continued GSK-3 inhibition or Wnt pathway activation promoted ESC differentiation into multipotent mesendodermal progenitors or their differential progenitors [293-295]. As stated previously, GSK-3 interacts with the Wnt, Hh and Notch pathways. These interactions can under the appropriate conditions regulate cell fate determination and maintenance of stem cells. GSK-3 can phosphorylate the GLI2 transcription factor, which can effect differentiation [296]. The self-renewal of ESCs was enhanced when they were cultured with leukemia inhibitory factor (LIF) and BMP3 and GSK-3 were suppressed. The mechanism responsible for the enhanced self-renewal is not clear. It was proposed that the expression of pluripotency factors such as Oct-4 and Nanog was prevented in these conditions [295]. GSK-3 may phosphorylate and inactivate other transcription factors associated with pluripotency, such as c-Myc and c-Jun. 48 derivatives of the GSK-3 inhibitor $1 \mathrm{i}$ were synthesized by Bone and colleagues. The abilities of these GSK-3 inhibitors to maintain undifferentiated ESCs were determined. The effectiveness of these compounds on maintaining undifferentiated ESCs was linked with inhibition of GSK-3 [297]. Thus GSK-3 inhibitors may be used to both maintain stem cell pluripotency as well as to expand these cells. These inhibitors may also be effective with induced pluripotent stem cell generation (iPSC) [295].

GSK-3 inhibitors may be appropriate for the treatment of certain diseases including: diabetes, obesity, ischemia, cancer, sepsis, colitis and neurological disorders. However, the evaluation of GSK-3 inhibitors in clinical trials has been hampered by the fear that inhibition of GSK-3 may stimulate or aid in malignant transformation as GSK-3 can phosphorylate such pro-oncogenic factors as beta-catenin, c-Jun and c-Myc which targets them for degradation [28]. However, no studies have been reported suggesting that treatment of mice with GSK-3 inhibitors resulted in an increase in cancer incidence. In contrast, studies in prostate, pancreatic, ovarian, thyroid, melanoma, brain, pheochromocytoma, paraganglioma, colorectal, and hematopoietic cancers have indicated that GSK-3 inhibitors could suppress proliferation [298]. In fact, many patients with bi-polar disorder have been treated with lithium for prolonged periods of time. There does not appear to be any evidence that these patients have increased incidences of cancer. In the studies by Wang et $a l$, treatment on mice with mixed-lineage leukemia (MLL) like leukemia (see below) with lithium actually increased the survival of the mice approximately $50 \%$.

Treatment of human leukemias containing $M L L$ translocations with GSK-3 inhibitors GSK-3 IX, SB216763, and allsterpaullone inhibited their growth of [64]. GSK-3beta activity was determined to be essential for the maintenance of MLL LSC. However GSK-3beta activity was not necessary for normal myeloid progenitors or progenitors transfected with other non- $M L L$ fusions. GSK-3alpha and GSK-3beta performed similar functions in regulating the growth of $M L L$-transformed leukemias. p2 $7^{\text {Kip-1 }}$ was critical for the effectiveness of the GSK3 inhibitors. Knock-down of p27 $7^{\text {Kip-1 }}$ prevented the growth arrest of the GSK-3 inhibitors specifically in $M L L$-transformed cells but not non- $M L L$ fusion proteintransformed cells. GSK-3 is believed to support the 
maintenance of $M L L$-transformed leukemic cells by promoting $\mathrm{p} 27^{\mathrm{Kip}-1}$ degradation. Upon treatment of the $M L L$-transformed cells with GSK-3 inhibitors, p2 $7^{\text {Kip-1 }}$ accumulated specifically in the $M L L$-transformed cells and cell cycle arrest occurred.

\section{Effects of Certain Small Molecule Inhibitors on GSK-3 Activity}

Certain small molecule inhibitors synergized with GSK-3beta inhibition to result in cell death [299]. The multi-kinase inhibitor sorafenib induced GSK-3beta which actually provides a survival signal in melanoma cells. When a constitutively-active form of $G S K 3 B$ was introduced into the melanoma cells, elevated levels of antiapoptotic Bcl-2, Bcl- $\mathrm{X}_{\mathrm{L}}$ and survivin were detected while decreased levels of pro-apoptotic Noxa were observed. Elimination of GSK-3beta activity increased the activity of sorafenib.

\section{Summary}

Many different biological processes are regulated by GSK-3 alpha and beta. GSK-3 interacts with many signaling pathways. Critical pathways often dysregulated in cancer are the PI3K/PTEN/Akt/mTORC1 and Wnt/ beta-catenin pathways. GSK-3 interacts with both Akt, TSC2 to regulate mTORC1. Akt has a negative effect on GSK-3 as when GSK-3 is phosphorylated by Akt, GSK-3 can not phosphorylate TSC2. This has a proproliferative effect as mTORC1 is not suppressed by TSC2. GSK-3 has a negative effect on mTORC as it phosphorylates and promotes the activity of TSC2 which inhibits mTORC1. This has an anti-proliferative effect. mTORC1 and GSK-3 also interact to regulate p70S6K which can indirectly regulate Akt. GSK-3 interacts with the Wnt/beta-catenin pathway at multiple levels; in some circumstances it inhibits the activity of Wnt/beta-catenin pathway by phosphorylation of beta-catanin which results in its proteasomal degradation, while in other cases it promotes the pathway by phosphorylating LRP5/6 which results in the stabilization of beta-catenin. This latter effect is especially prominent in certain CIC, where GSK3 inhibitors may prove clinically effective; however, they probably will have to be administered with betacatenin or downstream TCF/LEF inhibitors. GSK-3 also interacts with the Raf/MEK/ERK, Hh, Notch, and other important regulatory pathways. It is intriguing to consider why inhibiting GSK-3 does not have dire consequences as so many pathways will be affected which will lead to activation/suppression of various signaling pathways. However, the GSK-3 inhibitor lithium has been used to treat patients for many years now without apparent increases in the cancer incidence. GSK-3 is a kinase with many biochemical, biological and neurological effects.
Understanding of these effects may lead to improved therapies for certain diseases and conditions.

\section{ACKNOWLEDGMENTS}

ABD was supported in part by grants from the USAMRMC BC022276, the Intramural RECDA Award and the Italian Association for Cancer Research (AIRC). FEB was supported in part by a grant from the Triad Chapter of Golfers Against Cancer. LC was supported in part by MIUR-PRIN 2009 and Italian MIURFIRB Accordi di Programma 2010. MC and GM were supported in part by grants from the Italian "Ministero dell'Istruzione, dell'Università e della Ricerca (Ministry forEducation, Universities and Research) - FIRB-MERIT (RBNE08YYBM). MC was also supported in part by a grant to the CNR from the Italian Ministry of Economy and Finance for the Project FaReBio di Qualità. ML was supported in part by a grant from the Italian Ministry of Health, Ricerca Finalizzata Stemness 2008 entitled "Molecular Determinants of Stemness and Mesenchymal Phenotype in Breast Cancer". AMM was supported by MIUR FIRB 2011 (RBAP11ZJFA_001) grant. RM was supported in part by grants from: CRO, the Italian Association for Cancer Research, (AIRC) (RM PI grant and MCO10016), the Italian Ministry of Health, and Regione Friuli Venezia-Giulia.

\section{REFERENCES}

1. Embi N, Rylatt DB, Cohen P. Glycogen synthase kinase-3 from rabbit skeletal muscle. Separation from cyclic-AMPdependent protein kinase and phosphorylase kinase. Eur J Biochem. 1980; 107: 519-527.

2. Woodgett JR. Molecular cloning and expression of glycogen synthase kinase-3/factor A. EMBO J. 1990; 9: 2431-2438.

3. Gao C, Holscher C, Liu Y, Li L. GSK3: a key target for the development of novel treatments for type 2 diabetes mellitus and Alzheimer disease. Reviews in the Neurosciences. 2012; 23:1-11.

4. Forlenza OV, de Paula VJ, Machado-Vieira R, Diniz BS, Gattaz WF. Does lithium prevent Alzheimer's disease? Drugs \& Aging. 2012; 29: 335-342.

5. Amar S, Belmaker RH, Agam G. The possible involvement of glycogen synthase kinase-3 (GSK-3) in diabetes, cancer and central nervous system diseases. Current Pharmaceutical Design. 2011; 17: 2264-2277.

6. Juhaszova M, Zorov DB, Yaniv Y, Nuss HB, Wang S, Sollott SJ. Role of glycogen synthase kinase-3[beta] in cardioprotection. Circulation Research. 2009; 104: 12401252.

7. Shimura T. Acquired radioresistance of cancer and the AKT/GSK3beta/cyclin D1 overexpression cycle. Journal of Radiation Research. 2011; 52: 539-544. 
8. Fu Y, Hu D, Qiu J, Xie X, Ye F, Lu WG. Overexpression of glycogen synthase kinase-3 in ovarian carcinoma cells with acquired paclitaxel resistance. International Journal of Gynecological Cancer. 2011; 21: 439-444.

9. Kawazoe H, Bilim VN, Ugolkov AV, Yuuki K, Naito S, Nagaoka A, Kato T, Tomita Y. GSK-3 inhibition in vitro and in vivo enhances antitumor effect of sorafenib in renal cell carcinoma (RCC). Biochemical \& Biophysical Research Communications. 2012; 423: 490-495.

10. Thamilselvan V, Menon M, Thamilselvan S. Anticancer efficacy of deguelin in human prostate cancer cells targeting glycogen synthase kinase-3 beta/beta-catenin pathway. International Journal of Cancer. 2011; 129: 2916-2927.

11. Welham MJ, Kingham E, Sanchez-Ripoll Y, Kumpfmueller B, Storm M, Bone H. Controlling embryonic stem cell proliferation and pluripotency: the role of PI3K- and GSK3-dependent signalling. Biochemical Society Transactions. 2011; 39: 674-678.

12. Fung TK, Gandillet A, So CW. Selective treatment of mixed-lineage leukemia leukemic stem cells through targeting glycogen synthase kinase 3 and the canonical Wnt/ [beta]-catenin pathway. Current Opinion in Hematology. 2012; 19: 280-286.

13. Wray J, Kalkan T, Smith AG. The ground state of pluripotency. Biochemical Society Transactions. 2010; 38: 1027-1032.

14. Hur EM, Zhou FQ. GSK3 signalling in neural development. Nature Reviews Neuroscience. 2010; 11: 539-551.

15. Cheng H, Woodgett J, Maamari M, Force T. Targeting GSK-3 family members in the heart: a very sharp doubleedged sword. Journal of Molecular \& Cellular Cardiology. 2011; 51: 607-613.

16. Fu Y, Zheng S, An N, Athanasopoulos T, Popplewell L, Liang $\mathrm{A}, \mathrm{Li} \mathrm{K}, \mathrm{Hu} \mathrm{C}$, Zhu Y. beta-catenin as a potential key target for tumor suppression. International Journal of Cancer. 2011; 129: 1541-1551.

17. Palomo V, Perez DI, Gil C, Martinez A. The potential role of glycogen synthase kinase 3 inhibitors as amyotrophic lateral sclerosis pharmacological therapy. Current Medicinal Chemistry. 2011; 18: 3028-3034.

18. Li YC, Gao WJ. GSK-3beta activity and hyperdopaminedependent behaviors. Neurosci Biobehav Rev. 2011; 35: 645-654.

19. Wang H, Brown J, Martin M. Glycogen synthase kinase 3: a point of convergence for the host inflammatory response. Cytokine. 2011; 53: 130-140.

20. Trepiccione F, Christensen BM. Lithium-induced nephrogenic diabetes insipidus: new clinical and experimental findings. Journal of Nephrology. 2010; 23 Suppl 16: S43-48.

21. Klamer G, Song E, Ko KH, O’Brien TA, Dolnikov A. Using small molecule GSK3beta inhibitors to treat inflammation. Current Medicinal Chemistry. 2010; 17: 2873-2881.

22. Garcia I, Fall Y, Gomez G. QSAR, docking, and CoMFA studies of GSK3 inhibitors. Current Pharmaceutical Design. 2010; 16: 2666-2675.

23. Carter MD, Simms GA, Weaver DF. The development of new therapeutics for Alzheimer's disease. Clinical Pharmacology \& Therapeutics. 2010; 88: 475-486.

24. Henriksen EJ. Dysregulation of glycogen synthase kinase-3 in skeletal muscle and the etiology of insulin resistance and type 2 diabetes. Current Diabetes Reviews. 2010; 6: 285293.

25. Karam CS, Ballon JS, Bivens NM, Freyberg Z, Girgis RR, Lizardi-Ortiz JE, Markx S, Lieberman JA, Javitch JA. Signaling pathways in schizophrenia: emerging targets and therapeutic strategies. Trends in Pharmacological Sciences. 2010; 31: 381-390.

26. Kim YM, Seo YH, Park CB, Yoon SH, Yoon G. Roles of GSK3 in metabolic shift toward abnormal anabolism in cell senescence. Annals of the New York Academy of Sciences. 2010; 1201: 65-71.

27. Hoeflich KP, Luo J, Rubie EA, Tsao MS, Jin O, Woodgett JR. Requirement for glycogen synthase kinase-3beta in cell survival and NF-kappaB activation. Nature. 2000;406: 86-90.

28. Patel S, Woodgett. Glycogen synthase kinase-3 and cancer: good cop, bad cop? Cancer Cell. 2008; 14: 351-353.

29. Doble BW, Woodgett JR. GSK-3: tricks of the trade for a multi-tasking kinase. J Cell Sci. 2003; 116: 1175-1186.

30. Sutherland C. What are the bona fide GSK3 substrates? International journal of Alzheimer's Disease. 2011; Article ID 505607; 23 pages.

31. MacAulay K, Doble BW, Patel S, Hansotia T, Sinclair EM, Drucker DJ, Nagy A, Woodgett JR. Glycogen synthase kinase 3alpha-specific regulation of murine hepatic glycogen metabolism. Cell Metab. 2007; 6: 329-337.

32. Kaidanovich-Beilin O, Lipina TV, Takao K, van Eede M, Hattori S, Laliberté C, Khan M, Okamoto K, Chambers JW, Fletcher PJ, MacAulay K, Doble BW, Henkelman M, Miyakawa T, Roder J, Woodgett JR. Abnormalities in brain structure and behavior in GSK-3alpha mutant mice. Mol Brain. 2009; 2: 35.

33. Soutar MP, Kim WY, Williamson R, Peggie M, Hastie CJ, McLauchlan H, Snider WD, Gordon-Weeks PR, Sutherland C. J Evidence that glycogen synthase kinase-3 isoforms have distinct substrate preference in the brain. Neurochem. 2010; 115: 974-983.

34. Banerji V, Frumm SM, Ross KN, Li LS, Schinzel AC, Hahn CK, Kakoza RM, Chow KT, Ross L, Alexe G, Tolliday $\mathrm{N}$, Inguilizian H, Galinsky I, Stone RM, DeAngelo DJ, Roti G, Aster JC, Hahn WC, Kung AL, Stegmaier K. The intersection of genetic and chemical genomic screens identifies GSK-3alpha as a target in human acute myeloid leukemia. J Clin Invest. 2012; 122: 935-947.

35. Fang X, Yu SX, Lu Y, Bast RC Jr, Woodgett JR, Mills GB. Phosphorylation and inactivation of glycogen synthase kinase 3 by protein kinase A. Proc Natl Acad Sci USA. 
2000; 24: 97: 11960-11965.

36. Kim M, Datta A, Brakeman P, Yu W, Mostov KE. Polarity proteins PAR6 and aPKC regulate cell death through GSK3 beta in 3D epithelial morphogenesis. J Cell Sci. 2007; 120: 2309-2317.

37. Cross DA, Alessi DR, Cohen P, Andjelkovich M, Hemmings BA. Inhibition of glycogen synthase kinase-3 by insulin mediated by protein kinase B. Nature. 1995; 378: 785-789.

38. Stambolic V, Woodgett JR. Mitogen inactivation of glycogen synthase kinase- 3 beta in intact cells via serine 9 phosphorylation. Biochem J. 1994; 303: 701-704.

39. Sutherland $\mathrm{C}$, Leighton IA, Cohen P. Inactivation of glycogen synthase kinase-3 beta by phosphorylation: new kinase connections in insulin and growth-factor signalling. Biochem J. 1993; 296: 15-19.

40. Kockeritz L, Doble B, Patel S, Woodgett JR. Glycogen synthase kinase-3--an overview of an over-achieving protein kinase. Curr Drug Targets. 2006; 7: 1377-1388.

41. Saito Y, Vandenheede JR, Cohen P. The mechanism by which epidermal growth factor inhibits glycogen synthase kinase 3 in A431 cells. Biochem J. 1994; 303: 27-31.

42. Brady MJ, Bourbonais FJ, Saltiel AR. The activation of glycogen synthase by insulin switches from kinase inhibition to phosphatase activation during adipogenesis in 3T3-L1 cells. J Biol Chem. 1998; 273: 14063-14066.

43. Frame S, Cohen P, Biondi RM. A common phosphate binding site explains the unique substrate specificity of GSK3 and its inactivation by phosphorylation. Mol Cell. 2001; 7: 1321-1327.

44. Zhang N, Jiang Y, Zou J, Yu Q, Zhao W. Structural basis for the complete loss of GSK3beta catalytic activity due to R96 mutation investigated by molecular dynamics study. Proteins. 2009; 75: 671-681.

45. Cole A, Frame S, Cohen P. Further evidence that the tyrosine phosphorylation of glycogen synthase kinase-3 (GSK3) in mammalian cells is an autophosphorylation event. Biochem J. 2004; 377: 249-255.

46. Hughes K, Nikolakaki E, Plyte SE, Totty NF, Woodgett JR. Modulation of the glycogen synthase kinase-3 family by tyrosine phosphorylation. EMBO J. 1993; 12: 803-808.

47. Bhat RV, Shanley J, Correll MP, Fieles WE, Keith RA, Scott CW, Lee CM. Regulation and localization of tyrosine216 phosphorylation of glycogen synthase kinase-3beta in cellular and animal models of neuronal degeneration. Proc Natl Acad Sci USA. 2000; 97: 11074 11079.

48. Bijur GN, Jope RS. Proapoptotic stimuli induce nuclear accumulation of glycogen synthase kinase-3 beta. J Biol Chem. 2001; 276: 37436-37442.

49. Kang LJ, Lee HB, Bae HJ, Lee SG. Antidiabetic effect of propolis: reduction of expression of glucose-6-phosphatase through inhibition of Y279 and Y216 autophosphorylation of GSK-3 $\alpha / \beta$ in HepG2 cells. Phytother Res. 2010; 24:
$1554-1561$.

50. Pajak B, Songin M, Strosznajder JB, Gajkowska B. Alzheimer's disease genetic mutation evokes ultrastructural alterations: correlation to an intracellular Abeta deposition and the level of GSK-3beta-P(Y216) phosphorylated form. Neurotoxicology. 2009; 30: 581-588.

51. Songin M, Strosznajder JB, Fitał M, Kuter K, Kolasiewicz W, Nowak P, Ossowska K. Glycogen synthase kinase $3 \beta$ and its phosphorylated form (Y216) in the paraquat-induced model of parkinsonism. Neurotox Res. 2011; 19: 162-171.

52. Wang S, Toth ME, Bereczki E, Santha M, Guan ZZ, Winblad B, Pei JJ. Interplay between glycogen synthase kinase-3 $\beta$ and tau in the cerebellum of Hsp27 transgenic mouse. J Neurosci Res. 2011; 89: 1267-1275.

53. Hartigan JA, Xiong WC, Johnson GV. Glycogen synthase kinase 3 beta is tyrosine phosphorylated by PYK2. Biochem Biophys Res Commun. 2001; 284: 485-489.

54. Sayas CL, Ariaens A, Ponsioen B, Moolenaar WH. GSK3 is activated by the tyrosine kinase Pyk2 during LPA1mediated neurite retraction. Mol Biol Cell. 2006; 17: 18341844.

55. Medina M, Wandosell F. Deconstructing GSK-3: The fine regulation of its activity. Int J Alzheimers Dis. 2011; 2011:479249. doi: 10.4061/2011/479249. Epub 2011 Apr 28.

56. Lesort M, Jope RS, Johnson GV. Insulin transiently increases tau phosphorylation: involvement of glycogen synthase kinase-3beta and Fyn tyrosine kinase. J Neurochem. 1999; 72: 576-584.

57. Thornton TM, Pedraza-Alva G, Deng B, Wood CD, Aronshtam A, Clements JL, Sabio G, Davis RJ, Matthews DE, Doble B, Rincon M. Phosphorylation by p38 MAPK as an alternative pathway for GSK3beta inactivation. Science. 2008; 320: 667-670.

58. Bennecib M, Gong CX, Grundke-Iqbal I, Iqbal K. Role of protein phosphatase-2A and -1 in the regulation of GSK3 , cdk5 and cdc2 and the phosphorylation of tau in rat forebrain. FEBS Lett. 2000; 485: 87-93.

59. Kim L, Harwood A, Kimmel AR. Receptor-dependent and tyrosine phosphatase-mediated inhibition of GSK3 regulates cell fate choice. Dev Cell. 2002; 3: 523-532.

60. Tullai JW, Graham JR, Cooper GM. A GSK-3-mediated transcriptional network maintains repression of immediate early genes in quiescent cells. Cell Cycle. 2011; 10: 30723077.

61. Shin S, Wolgamott L, Yu Y, Blenis J, Yoon SO. Glycogen synthase kinase (GSK)-3 promotes p70 ribosomal protein S6 kinase (p70S6K) activity and cell proliferation. Proc Natl Acad Sci USA. 2011; 108: 1204-1213.

62. Shin S, Wolgamott L, Yoon SO. Glycogen synthase kinase (GSK)-3 and mammalian target of rapamycin complex 1 (mTORC1) cooperate to regulate protein S6 kinase 1 (S6K1). Cell Cycle. 2012; 11: 1053-1054.

63. McQueen J, van Dyk D, Young B, Loewen C, Measday V. 
The Mck1 GSK-3 kinase inhibits the activity of Clb2-Cdk1 post-nuclear division. Cell Cycle. 2012; 11: 3421-3432.

64. Wang Z, Smith KS, Murphy M, Piloto O, Somervaille TC, Cleary ML. Glycogen synthase kinase 3 in MLL leukaemia maintenance and targeted therapy. Nature. 2008; 455: 1205 1209.

65. Rossig L, Badorff C, Holzmann Y, Zeiher AM, Dimmeler S: Glycogen synthase kinase-3 couples AKT-dependent signaling to the regulation of $\mathrm{p} 21 \mathrm{Cip} 1$ degradation. J Biol Chem. 2002; 277: 9684-9689.

66. Diehl JA, Cheng M, Roussel MF, Sherr CJ. Glycogen synthase kinase- 3beta regulates cyclin D1 proteolysis and subcellular localization. Genes Dev. 1998; 12: 3499-3511.

67. Welcker M, Singer J, Loeb KR, Grim J, Bloecher A, Gurien-West M, Clurman BE, Roberts JM. Multisite phosphorylation by $\mathrm{Cdk} 2$ and GSK3 controls cyclin E degradation. Mol Cell. 2003; 12: 381-392.

68. Leis H, Segrelles C, Ruiz S, Santos M, Paramio JM. Expression, localization, and activity of glycogen synthase kinase 3beta during mouse skin tumorigenesis. Mol Carcinog. 2002; 35: 180-185.

69. Mishra R. Glycogen synthase kinase 3 beta: can it be a target for oral cancer? Molecular Cancer. 2010; 9: 144.

70. Yada M, Hatakeyama S, Kamura T, Nishiyama M, Tsunematsu R, Imaki H, Ishida N, Okumura F, Nakayama K, Nakayama KI. Phosphorylation-dependent degradation of c-Myc is mediated by the F-box protein Fbw7. EMBO J. 2004; 23: 2116-2125.

71. Hoeflich KP, Luo J, Rubie EA, Tsao MS, Jin O, Woodgett JR. Requirement for glycogen synthase kinase-3beta in cell survival and NF-kappaB activation. Nature. 2000; 406: 86-90.

72. Barre B, Perkins ND. Phosphorylation of the p52 NFkappaB subunit. Cell Cycle. 2010; 9: 4774-4775.

73. Haraguchi M, Okubo T, Miyashita Y, Miyamoto Y, Hayashi M, Crotti TN, McHugh KP, Ozawa M. Snail regulates cellmatrix adhesion by regulation of the expression of integrins and basement membrane proteins. J Biol Chem. 2008; 283: 23514-23523.

74. Yook JI, Li XY, Ota I, Hu C, Kim HS, Kim NH, Cha SY, Ryu JK, Choi YJ, Kim J, Fearon ER, Weiss SJ. A WntAxin2-GSK3beta cascade regulates Snaill activity in breast cancer cells. Nat Cell Biol. 2006; 8: 1398-1406.

75. Foltz DR, Santiago MC, Berechid BE, Nye JS. Glycogen synthase kinase-3beta modulates notch signaling and stability. Curr Biol. 2002; 12: 1006-1011.

76. Kashikar ND, Zhang W, Massion PP, Gonzalez AL, Datta PK. Role of STRAP in regulating GSK3beta function and Notch3 stabilization. Cell Cycle. 2011; 10: 1639-1654.

77. G-Amlak M, Uddin S, Mahmud D, Damacela I, Lavelle D, Ahmed M, van Besien K, Wickrema A. Regulation of myeloma cell growth through Akt/Gsk3/forkhead signaling pathway. Biochem Biophys Res Commun. 2002; 297: 760764.
78. Ross SE, Erickson RL, Hemati N, MacDougald OA. Glycogen synthase kinase 3 is an insulin-regulated $\mathrm{C} /$ EBPalpha kinase. Mol Cell Biol. 1999; 19: 8433-8441.

79. de Groot RP, Auwerx J, Bourouis M, Sassone-Corsi P. Negative regulation of Jun/AP-1: conserved function of glycogen synthase kinase 3 and the Drosophila kinase shaggy. Oncogene. 1993; 8: 841-847.

80. Buss H, Dorrie A, Schmitz ML, Frank R, Livingstone M, Resch K, Kracht M. Phosphorylation of serine 468 by GSK3 beta regulates basal p65 NF-kappaB activity. J Biol Chem. 2004; 279: 49571-49574.

81. Ma Y, Wang M, Li N, Wu R, Wang X. Bleomycin-induced nuclear factor kappaB activation in human bronchial epithelial cells involves the phosphorylation of glycogen synthase kinase 3beta. Toxicol Lett. 2009; 187: 194-200.

82. Sanchez JF, Sniderhan LF, Williamson AL, Fan S, Chakraborty-Sett S, Maggirwar SB. Glycogen synthase kinase 3beta-mediated apoptosis of primary cortical astrocytes involves inhibition of nuclear factor kappaB signaling. Mol Cell Biol. 2003; 23: 4649-4662.

83. Qu L, Huang S, Baltzis D, Rivas-Estilla AM, Pluquet O, Hatzoglou M, Koumenis C, Taya Y, Yoshimura A, Koromilas AE. Endoplasmic reticulum stress induces p53 cytoplasmic localization and prevents p53-dependent apoptosis by a pathway involving glycogen synthase kinase3beta. Genes Dev. 2004; 18: 261-277.

84. Charvet C, Maurer U. GSK-3 turns p53 deadly. Cell Cycle. 2011; 10: 3621-3622.

85. Kim NH, Kim HS, Li XY, Lee I, Choi HS, Kang SE, Cha SY, Ryu JK, Yoon D, Fearon ER, Rowe RG, Lee S, Maher CA, Weiss SJ, Yook JI. A p53/miRNA-34 axis regulates Snaill-dependent cancer cell epithelial-mesenchymal transition. J Cell Biol. 2011; 195: 417-433.

86. Kim NH, Kim HS, Kim NG, Lee I, Choi HS, Li XY, Kang SE, Cha SY, Ryu JK, Na JM, Park C, Kim K, Lee S, Gumbiner BM, Yook JI, Weiss SJ. p53 and microRNA-34 are suppressors of canonical Wnt signaling. Sci Signal. 2011; 4: ra71.

87. Bianchi M, De Lucchini S, Marin O, Turner DL, Hanks SK, Villa-Moruzzi E. Regulation of FAK Ser-722 phosphorylation and kinase activity by GSK3 and PP1 during cell spreading and migration. Biochem J. 2005; 391 : 359-370.

88. Batlle E, Sancho E, Francí C, Domínguez D, Monfar M, Baulida J, García De Herreros A. The transcription factor snail is a repressor of E-cadherin gene expression in epithelial tumour cells. Nat Cell Biol. 2000; 2: 84-89.

89. Bachelder RE, Yoon SO, Franci C, de Herreros AG, Mercurio AM. Glycogen synthase kinase-3 is an endogenous inhibitor of Snail transcription: implications for the epithelial-mesenchymal transition. J Cell Biol. 2005; 168: 29-33.

90. Bauer K, Dowejko A, Bosserhoff AK, Reichert TE, Bauer RJ. P-cadherin induces an epithelial-like phenotype in oral 
squamous cell carcinoma by GSK-3beta-mediated Snail phosphorylation. Carcinogenesis. 2009; 30: 1781-1788.

91. Wang H, Wang HS, Zhou BH, Li CL, Zhang F, Wang XF, Zhang G, Bu XZ, Cai SH, Du J. Epithelial-mesenchymal transition (EMT) induced by TNF- $\alpha$ requires AKT/GSK$3 \beta$-mediated stabilization of snail in colorectal cancer. PLoS One. 2013;8(2):e56664.

92. Zheng H, Li W, Wang Y, Liu Z, Cai Y, Xie T, Shi M, Wang $Z$, Jiang B. Glycogen synthase kinase-3beta regulates Snail and $\beta$-catenin expression during Fas-induced epithelialmesenchymal transition in gastrointestinal cancer. Eur J Cancer. 2013; 49: 2734-2746.

93. Wen W, Ding J, Sun W, Fu J, Chen Y, Wu K, Ning B, Han T, Huang L, Chen C, Xie D, Li Z, Feng G, Wu M, Xie W, Wang H. Cyclin G1-mediated epithelial-mesenchymal transition via phosphoinositide 3-kinase/Akt signaling facilitates liver cancer progression. Hepatology. 2012; 55: 1787-1798.

94. Liu H, Xu L, He H, Zhu Y, Liu J, Wang S, Chen L, Wu Q, $\mathrm{Xu} \mathrm{J}, \mathrm{Gu}$ J. Hepatitis B virus X protein promotes hepatoma cell invasion and metastasization by stabilizing Snail protein. Cancer Sci. 2012; 103: 2072-2081.

95. Liu L, Dai Y, Chen J, Zeng T, Li Y, Chen L, Zhu YH, Li J, Li Y, Ma S, Xie D, Yuan YF, Guan XY. Maelstrom promotes hepatocellular carcinoma metastasis by inducing epithelial-mesenchymal transition by way of Akt/GSK-3 $\beta /$ Snail signaling. Hepatology. 2014; 59: 531-543.

96. Belkhiri A, Dar AA, Zaika A, Kelley M, El-Rifai W. t-Darpp promotes cancer cell survival by up-regulation of Bcl2 through Akt-dependent mechanism. Cancer Res. 2008; 68: 395-403.

97. Ding Q, He X, Hsu JM, Xia W, Chen CT, Li LY, Lee DF, Liu JC, Zhong Q, Wang X, Hung MC. Degradation of Mcl-1 by beta-TrCP mediates glycogen synthase kinase 3 -induced tumor suppression and chemosensitization. Molecular \& Cellular Biology. 2007; 27: 4006-4017.

98. Morel C, Carlson SM, White FM, Davis RJ. Mcl-1 integrates the opposing actions of signaling pathways that mediate survival and apoptosis. Mol Cell Biol. 2009; 29: 3845-3852.

99. Inuzuka H, Fukushima H, Shaik S, Liu P, Lau AW, Wei W. Mcl-1 ubiquitination and destruction. Oncotarget. 2011; 2: 239-244.

100. Nifoussi SK, Vrana JA, Domina AM, De Biasio A, Gui J, Gregory MA, Hann SR, Craig RW. Thr 163 phosphorylation causes Mcl-1 stabilization when degradation is independent of the adjacent GSK3-targeted phosphodegron, promoting drug resistance in cancer. PLoS One. 2012; 7(10): e47060. doi: 10.1371/ journal.

101. Zhao Y, Altman BJ, Coloff JL, Herman CE, Jacobs SR, Wieman HL, Wofford JA, Dimascio LN, Ilkayeva O, Kelekar A, Reya T, Rathmell JC. Glycogen synthase kinase 3alpha and 3 beta mediate a glucose-sensitive antiapoptotic signaling pathway to stabilize Mcl-1. Molecular \& Cellular
Biology. 2007; 27: 4328-4339.

102. Cheng YL, Huang WC, Chen CL, Tsai CC, Wang CY, Chiu WH, Chen YL Lin YS, Chang CF, Lin CF. Increased galectin-3 facilitates leukemia cell survival from apoptotic stimuli. Biochem Biophys Res Commun. 2011; 412: 334340.

103. Chou CH, Chou AK, Lin CC, Chen WJ, Wei CC, Yang MC, Hsu CM, Lung FW, Loh JK, Howng SL, Hong YR. GSK3beta regulates Bcl2L12 and Bcl2L12A anti-apoptosis signaling in glioblastoma and is inhibited by $\mathrm{LiCl}$. Cell Cycle. 2012; 11: 532-542.

104. Hsing CH, Chen YH, Chen CL, Huang WC, Lin MC, Tseng PC, Wang CY, Tsai CC, Choi PC, Lin CF. Anesthetic propofol causes glycogen synthase kinase-3[beta]-regulated lysosomal/mitochondrial apoptosis in macrophages. Anesthesiology. 2012; 116: 868-881.

105. Zhou F, Zhang L, van Laar T, van Dam H, Ten Dijke P. GSK3beta inactivation induces apoptosis of leukemia cells by repressing the function of c-Myb. Mol Biol Cell. 2011; 22: 3533-3540.

106. Marchand B, Tremblay I, Cagnol S, Boucher MJ. Inhibition of glycogen synthase kinase-3 activity triggers an apoptotic response in pancreatic cancer cells through JNK-dependent mechanisms. Carcinogenesis. 2012; 33: 529-537.

107. Linseman DA, Butts BD, Precht TA, Phelps RA, Le SS, Laessig TA, Bouchard RJ, Florez-McClure ML, Heidenreich KA. Glycogen synthase kinase-3beta phosphorylates $\mathrm{Bax}$ and promotes its mitochondrial localization during neuronal apoptosis. Journal of Neuroscience. 2004; 24: 9993-10002.

108. Tan J, Zhuang L, Leong HS, Iyer NG, Liu ET, Yu Q. Pharmacologic modulation of glycogen synthase kinase3beta promotes $\mathrm{p} 53$-dependent apoptosis through a direct Bax-mediated mitochondrial pathway in colorectal cancer cells. Cancer Res. 2005; 65: 9012-9020.

109. Rocques N, Abou Zeid N, Sii-Felice K, Lecoin L, FelderSchmittbuhl MP, Eychène A, Pouponnot C. GSK-3mediated phosphorylation enhances Maf-transforming activity. Mol Cell. 2007; 28: 584-597.

110. Wang Y, van der Zee M, Fodde R, Blok LJ. Wnt/B-catenin and sex hormone signaling in endometrial homeostasis and cancer. Oncotarget. 2010; 1: 674-684.

111. Chen X, Stoeck A, Lee SJ, Shih IeM, Wang MM, Wang TL. Jagged 1 expression regulated by Notch 3 and Wnt/betacatenin signaling pathways in ovarian cancer. Oncotarget. 2010; 1: 210-218.

112. Curtin JC, Lorenzi MV. Drug discovery approaches to target Wnt signaling in cancer stem cells. Oncotarget. 2010; 1: 563-577.

113. Pacheco-Pinedo EC, Morrisey EE. Wnt and Kras signalingdark siblings in lung cancer. Oncotarget. 2011; 2: 569-574.

114. Velpula KK, Dasari VR, Tsung AJ, Dinh DH, Rao JS. Cord blood stem cells revert glioma stem cell EMT by down regulating transcriptional activation of Sox 2 and Twist1. 
Oncotarget. 2011; 2: 1028-1042.

115. Jaitner S, Reiche JA, Schaffauer AJ, Hiendlmeyer E, Herbst H, Brabletz T, Kirchner T, Jung A. Human telomerase reverse transcriptase (hTERT) is a target gene of betacatenin in human colorectal tumors. Cell Cycle. 2012; 11 : 3331-3338.

116. Singh AM, Bechard M, Smith K, Dalton S. Reconciling the different roles of Gsk3beta in "naive" and "primed" pluripotent stem cells. Cell Cycle. 2012; 11: 2991-2996.

117. Conrad WH, Swift RD, Biechele TL, Kulikauskas RM, Moon RT, Chien AJ. Regulating the response to targeted MEK inhibition in melanoma: Enhancing apoptosis in NRAS- and BRAF-mutant melanoma cells with Wnt/betacatenin activation. Cell Cycle. 2012; 11: 3724-3730.

118. Cha YH, Kim NH, Park C, Lee I, Kim HS, Yook JI. MiRNA-34 intrinsically links p53 tumor suppressor and Wnt signaling. Cell Cycle. 2012; 11: 1273-1281.

119. Genovese G, Ghosh P, Li H, Rettino A, Sioletic S, Cittadini A, Sgambato A. The tumor suppressor HINT1 regulates MITF and beta-catenin transcriptional activity in melanoma cells. Cell Cycle. 2012; 11: 2206-2215.

120. Gall JM1, Wong V, Pimental DR, Havasi A, Wang Z, Pastorino JG, Bonegio RG, Schwartz JH, Borkan SC. Hexokinase regulates Bax-mediated mitochondrial membrane injury following ischemic stress. Kidney Int. 2011; 79: 1207-1216.

121. Gizak A, Pirog M, Rakus D. Muscle FBPase binds to cardiomyocyte mitochondria under glycogen synthase kinase-3 inhibition or elevation of cellular $\mathrm{Ca} 2+$ level. FEBS Lett. 2012; 586: 13-19.

122. Luo J. Glycogen synthase kinase 3beta (GSK3beta) in tumorigenesis and cancer chemotherapy. Cancer Lett. 2009; 273: 194-200.

123. Shakoori A, Ougolkov A, Yu ZW, Zhang B, Modarressi MH, Billadeau DD, Mai M, Takahashi Y, Minamoto T. Deregulated GSK3beta activity in colorectal cancer: its association with tumor cell survival and proliferation. Biochem Biophys Res Commun. 2005; 334: 1365-1373.

124. Ougolkov AV, Fernandez-Zapico ME, Savoy DN, Urrutia RA, Billadeau DD. Glycogen synthase kinase-3beta participates in nuclear factor kappaB-mediated gene transcription and cell survival in pancreatic cancer cells. Cancer Res. 2005; 65: 2076-2081.

125. Zhou W, Wang L, Gou SM, Wang TL, Zhang M, Liu T, Wang CY. shRNA silencing glycogen synthase kinase-3 beta inhibits tumor growth and angiogenesis in pancreatic cancer. Cancer Letters. 2012; 316: 178-186.

126. Farago M, Dominguez I, Landesman-Bollag E, Xu X, Rosner A, Cardiff RD, Seldin DC. Kinase-inactive glycogen synthase kinase 3 beta promotes Wnt signaling and mammary tumorigenesis. Cancer Res. 2005; 65: 5792-5801.

127. Ma C, Wang J, Gao Y, Gao TW, Chen G, Bower KA, Odetallah M, Ding M, Ke Z, Luo J. The role of glycogen synthase kinase 3 beta in the transformation of epidermal cells. Cancer Res. 2007; 67: 7756-7764.

128. Dong J, Peng J, Zhang H, Mondesire WH, Jian W, Mills GB, Hung MC, Meric-Bernstam F. Role of glycogen synthase kinase 3 beta in rapamycin-mediated cell cycle regulation and chemosensitivity. Cancer Res. 2005; 65: 1961-1972.

129. Dal Col J, Dolcetti R. GSK-3beta inhibition: at the crossroad between Akt and mTOR constitutive activation to enhance cyclin D1 protein stability in mantle cell lymphoma. Cell Cycle. 2008; 7: 2813-2816.

130. Wang Y, Lam JB, Lam KS, Liu J, Lam MC, Hoo RL, Wu D, Cooper GJ, Xu A. Adiponectin modulates the glycogen synthase kinase-3beta/betacatenin signaling pathway and attenuates mammary tumorigenesis of MDA-MB-231 cells in nude mice. Cancer Res. 2006; 66: 11462-11470.

131. Bartkova J, Lukas J, Müller H, Lützhøft D, Strauss M, Bartek J. Cyclin D1 protein expression and function in human breast cancer. Int J Cancer. 1994; 57: 353-361.

132. Gillett C, Fantl V, Smith R, Fisher C, Bartek J, Dickson C, Barnes D, Peters G. Amplification and overexpression of cyclin D1 in breast cancer detected by immunohistochemical staining. Cancer Res. 1994; 54: 1812-1817.

133. Dickson C, Fantl V, Gillett C, Brookes S, Bartek J, Smith R, Fisher C, Barnes D, Peters G. Amplification of chromosome band 11q13 and a role for cyclin D1 in human breast cancer. Cancer Lett. 1995; 90: 43-50.

134. Lin SY, Xia W, Wang JC, Kwong KY, Spohn B, Wen Y, Pestell RG, Hung MC. Beta-catenin, a novel prognostic marker for breast cancer: its roles in cyclin D1 expression and cancer progression. Proc Natl Acad Sci USA. 2000; 97 : 4262-4266.

135. Hsu W, Shakya R, Costantini F. Impaired mammary gland and lymphoid development caused by inducible expression of Axin in transgenic mice. J Cell Biol. 2001; 155: 10551064.

136. Landesman-Bollag E, Song DH, Romieu-Mourez R, Sussman DJ, Cardiff RD, Sonenshein GE, Seldin DC. Protein kinase CK2: signaling and tumorigenesis in the mammary gland. Mol Cell Biochem. 2001; 227: 153-165.

137. Sokolosky M, Chappell WH, Stadelman K, Abrams SL, Davis NM, Steelman LS, McCubrey JA. Inhibition of GSK$3 \beta$ activity can result in drug and hormonal resistance and alter sensitivity to targeted therapy in MCF-7 breast cancer cells. Cell Cycle. 2014 In Press.

138. Bahram F, von der Lehr N, Cetinkaya C, Larsson LG. c-Myc hot spot mutations in lymphomas result in inefficient ubiquitination and decreased proteasome-mediated turnover. Blood. 2000; 95: 2104-2110.

139. Oster SK, Ho CS, Soucie EL, Penn LZ. The myc oncogene: MarvelouslY Complex. Adv Cancer Res. 2002; 84: 81-154.

140. Gregory MA, Qi Y, Hann SR. Phosphorylation by glycogen synthase kinase-3 controls c-myc proteolysis and subnuclear localization. J Biol Chem. 2003; 278: 51606-51612. 
141. An J, Yang DY, Xu QZ, Zhang SM, Huo YY, Shang ZF, Wang Y, Wu DC, Zhou PK. DNA-dependent protein kinase catalytic subunit modulates the stability of c-Myc oncoprotein. Mol Cancer. 2008; 7: 32.

142. de Castro J, Gamallo C, Palacios J, Moreno-Bueno G, Rodriguez N, Feliu J, Gonzalez-Baron M. beta-catenin expression pattern in primary oesophageal squamous cell carcinoma. Relationship with clinicopathologic features and clinical outcome. Virchows Arch. 2000; 437: 599-604.

143. Amit S, Hatzubai A, Birman Y, Andersen JS, Ben-Shushan E, Mann M, Ben-Neriah Y, Alkalay I. Axin-mediated CKI phosphorylation of beta-catenin at Ser 45: a molecular switch for the Wnt pathway. Genes Dev. 2002; 16: 10661076 .

144. Iwai S, Katagiri W, Kong C, Amekawa S, Nakazawa M, Yura Y. Mutations of the APC, beta-catenin, and axin 1 genes and cytoplasmic accumulation of beta-catenin in oral squamous cell carcinoma. J Cancer Res Clin Oncol. 2005; 131: 773-782.

145. Yeh KT, Chang JG, Lin TH, Wang YF, Chang JY, Shih $\mathrm{MC}$, Lin CC. Correlation between protein expression and epigenetic and mutation changes of Wnt pathway-related genes in oral cancer. Int J Oncol. 2003; 23: 1001-1007.

146. Sokolosky ML, Stadelman KM, Chappell WH, Abrams SL, Martelli AM, Stivala F, Libra M, Nicoletti F, Drobot LB, Franklin RA, Steelman LS, McCubrey JA. Involvement of Akt-1 and mTOR in sensitivity of breast cancer to targeted therapy. Oncotarget. 2011; 2: 538-550.

147. Taylor JR, Lehmann BD, Chappell WH, Abrams SL, Steelman LS, McCubrey JA. Cooperative effects of Akt1 and Raf-1 on the induction of cellular senescence in doxorubicin or tamoxifen treated breast cancer cells. Oncotarget. 2011; 2: 610-626.

148. Hafsi S, Pezzino FM, Candido S, Ligresti G, Spandidos DA, Soua Z, McCubrey JA, Travali S, Libra M. Gene alterations in the PI3K/PTEN/AKT pathway as a mechanism of drugresistance Int J Oncol. 2012; 40: 639-644.

149. Steelman LS, Navolanic P, Chappell WH, Abrams SL, Wong EW, Martelli AM, Cocco L, Stivala F, Libra M, Nicoletti F, Drobot LB, Franklin RA, McCubrey JA. Involvement of Akt and mTOR in chemotherapeutic- and hormonal-based drug resistance and response to radiation in breast cancer cells. Cell Cycle. 2011; 10: 3003-3015.

150. Martelli AM, Evangelisti C, Chappell W, Abrams SL, Bäsecke J, Stivala F, Donia M, Fagone P, Nicoletti F, Libra M, Ruvolo V, Ruvolo P, Kempf CR, Steelman LS, McCubrey JA. Targeting the translational apparatus to improve leukemia therapy: roles of the PI3K/PTEN/Akt/ mTOR pathway. Leukemia. 2011; 25: 1064-1079.

151. Steelman LS, Chappell WH, Abrams SL, Kempf RC, Long J, Laidler P, Mijatovic S, Maksimovic-Ivanic D, Stivala F, Mazzarino MC, Donia M, Fagone P, Malaponte G, Nicoletti F, Libra M, Milella M, et al. Roles of the Raf/MEK/ERK and PI3K/PTEN/Akt/mTOR pathways in controlling growth and sensitivity to therapy-implications for cancer and aging. Aging. 2011; 3: 192-222.

152. Hart JR, Vogt PK. Phosphorylation of AKT: a mutational analysis. Oncotarget. 2011; 2: 467-476.

153. Zawel L. P3Kalpha: a driver of tumor metastasis? Oncotarget. 2010; 1: 315-316.

154. Schmidt-Kittler O, Zhu J, Yang J, Liu G, Hendricks W, Lengauer C, Gabelli SB, Kinzler KW, Vogelstein B, Huso DL, Zhou S. PI3Kalpha inhibitors that inhibit metastasis. Oncotarget. 2010; 1: 339-348.

155. Garrett JT, Chakrabarty A, Arteaga CL. Will PI3K pathway inhibitors be effective as single agents in patients with cancer? Oncotarget. 2011; 2: 1314-1321.

156. Sander S, Rajewsky K. Burkitt lymphomagenesis linked to MYC plus PI3K in germinal center B cells. Oncotarget. 2012; 3: 1066-1067.

157. Alinari L, Christian B, Baiocchi RA. Novel targeted therapies for mantle cell lymphoma. Oncotarget. 2012; 3: 203-211.

158. Antico Arciuch VG, Russo MA, Dima M, Kang KS, Dasrath F, Liao XH, Refetoff S, Montagna C, Di Cristofano A. Thyrocyte-specific inactivation of p53 and Pten results in anaplastic thyroid carcinomas faithfully recapitulating human tumors. Oncotarget. 2011; 2: 1109-1126.

159. Weber GL, Parat MO, Binder ZA, Gallia GL, Riggins GJ. Abrogation of PIK3CA or PIK3R1 reduces proliferation, migration, and invasion in glioblastoma multiforme cells. Oncotarget. 2011; 2: 833-849.

160. Dbouk HA, Backer JM. A beta version of life: p110beta takes center stage. Oncotarget. 2010; 1: 729-733.

161. Burger JA, Hoellenriegel J. Phosphoinositide 3'-kinase delta: turning off BCR signaling in chronic lymphocytic leukemia. Oncotarget. 2011; 2: 737-738.

162. Adams JR, Schachter NF, Liu JC, Zacksenhaus E, Egan SE. Elevated PI3K signaling drives multiple breast cancer subtypes. Oncotarget. 2011; 2: 435-447.

163. Agoulnik IU, Hodgson MC, Bowden WA, Ittmann MM. INPP4B: the new kid on the PI3K block. Oncotarget. 2011; 2: 321-328.

164. Martelli AM, Chiarini F, Evangelisti C, Cappellini A, Buontempo F, Bressanin D, Fini M, McCubrey JA. Dual Inhibitors of phosphatidylinositol 3-kinase and mammalian target of rapamycin: a novel therapeutic strategy for acute leukemia treatment? Oncotarget. 2012; 3: 371-394.

165. Martelli AM, Chiarini F, Evangelisti C, Ognibene A, Bressanin D, Billi AM, Manzoli L, Cappellini A, McCubrey JA. Targeting the liver Kinase B1/AMP-dependent kinase pathway as a therapeutic strategy for hematological malignancies. Expert Opinion Therapeutic Targets. 2012; 16: 729-742.

166. Peterson TR, Laplante M, Thoreen CC, Sancak Y, Kang SA, Kuehl WM, Gray NS, Sabatini DM. DEPTOR is an mTOR inhibitor frequently overexpressed in multiple myeloma cells and required for their survival. Cell. 2009; 137: 873-886. 
167. Chiarini F, Lonetti A, Teti G, Orsini E, Bressanin D, Cappellini A, Ricci F, Tazzari PL, Ognibene A, Falconi M, Pagliaro P, Iacobucci I, Martinelli G, Amadori S, McCubrey JA, Martelli AM. A combination of temsirolimus, an allosteric mTOR inhibitor, with clofarabine as a new therapeutic option for patients withacute myeloid leukemia. Oncotarget. 2012, 3: 1615-1628.

168. Bressanin D, Evangelisti C, Ricci F, Tabellini G, Chiarini F, Tazzari PL, Melchionda F, Buontempo F, Pagliaro P, Pession A, McCubrey JA, Martelli AM. Harnessing the $\mathrm{PI} 3 \mathrm{~K} / \mathrm{Akt} / \mathrm{mTOR}$ pathway in T-cell acute lymphoblastic leukemia: eliminating activity by targeting at different levels. Oncotarget. 2012; 3: 811-823.

169. McCubrey JA, Steelman LS, Bertrand FE, Davis NM, Abrams SL, Montalto G, D'Assoro AB, Libra M, Nicoletti F, Maestro R, Basecke J, Cocco L, Cervello M, Martelli AM.Multifaceted roles of GSK-3 and Wnt/ $\beta$-catenin in hematopoiesis and leukemogenesis: opportunities for therapeutic intervention. Leukemia. 2014; 28:15-33.

170. Grimaldi C, Chiarini F, Tabellini G, Ricci F, Tazzari PL, Battistelli M, Falcieri E, Bortul R, Melchionda F, Iacobucci I, Pagliaro P, Martinelli G, Pession A, Barata JT, McCubrey JA, Martelli AM. AMP-dependent kinase/mammalian target of rapamycin complex 1 signaling in T-cell acute lymphoblastic leukemia: therapeutic implications. Leukemia. 2012; 26: 91-100.

171. Martelli AM, Chiarini F, Evangelisti C, Ognibene A, Bressanin D, Billi AM, Manzoli L, Cappellini A, McCubrey JA. Targeting the liver kinase B1/AMP-activated protein kinase pathway as a therapeutic strategy for hematological malignancies. Expert Opin Ther Targets. 2012; 16: 729742.

172. Habib SL. Mechanism of activation of AMPK and upregulation of OGG1 by rapamycin in cancer cells. Oncotarget. 2011; 2: 958-959.

173. Jansen M, Ten Klooster JP, Offerhaus GJ, Clevers H. LKB1 and AMPK family signaling: the intimate link between cell polarity and energy metabolism. Physiol Rev. 2009; 89: 777-798.

174. van der Velden YU, Haramis AP. Insights from model organisms on the functions of the tumor suppressor protein LKB1: zebrafish chips in. Aging. 2011; 3: 363-367.

175. Godlewski J, Bronisz A, Nowicki MO, Chiocca EA, Lawler S. microRNA-451: A conditional switch controlling glioma cell proliferation and migration. Cell Cycle. 2010; 9: 27422748.

176. Liu B, Fan Z, Edgerton SM, Yang X, Lind SE, Thor AD. Potent anti-proliferative effects of metformin on trastuzumab-resistant breast cancer cells via inhibition of erbB2/IGF-1 receptor interactions. Cell Cycle. 2011; 10: 2959-2966.

177. Vazquez-Martin A, Oliveras-Ferraros C, Cufi S, MartinCastillo B, Menendez JA. Metformin activates an ataxia telangiectasia mutated (ATM)/Chk2-regulated DNA damage-like response. Cell Cycle. 2011; 10: 1499-1501.
178. Mashhedi H, Blouin MJ, Zakikhani M, David S, Zhao Y, Bazile M, Birman E, Algire C, Aliaga A, Bedell BJ, Pollak M. Metformin abolishes increased tumor (18)F-2-fluoro-2deoxy-D-glucose uptake associated with a high energy diet. Cell Cycle. 2011; 10: 2770-2778.

179. Oliveras-Ferraros C, Cufi S, Vazquez-Martin A, TorresGarcia VZ, Del Barco S, Martin-Castillo B, Menendez JA. Micro(mi)RNA expression profile of breast cancer epithelial cells treated with the anti-diabetic drug metformin: induction of the tumor suppressor miRNA let-7a and suppression of the TGFbeta-induced oncomiR miRNA-181a. Cell Cycle. 2011; 10: 1144-1451.

180. Chappell WH, Abrams SL, Franklin RA, Lahair MM, Montalto G, Cervello M, Martelli AM, Nicoletti F, Candido S, Libra M, Polesel J, Talamini R, Milella M, Tafuri A, Steelman LS, McCubrey JA. Ectopic NGAL expression can alter sensitivity of breast cancer cells to EGFR, Bcl-2, $\mathrm{CaM}-\mathrm{K}$ inhibitors and the plant natural product berberine. Cell Cycle. 2012; 11: 4447-4461.

181. Krymskaya VP, Goncharova EA. PI3K/mTORC1 activation in hamartoma syndromes: therapeutic prospects. Cell Cycle. 2009; 8: 403-413.

182. Sato T, Nakashima A, Guo L, Tamanoi F. Specific activation of mTORC1 by Rheb G-protein in vitro involves enhanced recruitment of its substrate protein. J Biol Chem. 2009; 284: 12783-12791.

183. McCubrey JA, Steelman LS, Chappell WH, Abrams SL, Franklin RA, Montalto G, Cervello M, Nicoletti F, Fagone P, Malaponte G, Mazzarino MC, Candido S, Libra M, Bäsecke J, Milella M, Tafuri A, et al. Mutations and deregulation of Ras/Raf/MEK/ERK and PI3K/PTEN/Akt/ mTOR cascades which alter therapy response. Oncotarget. 2012; 3: 954-987.

184. McCubrey JA, Steelman LS, Chappell WH, Abrams SL, Montalto G, Cervello M, Nicoletti F, Fagone P, Malaponte G, Mazzarino MC, Candido S, Libra M, Bäsecke J, Mijatovic S, Maksimovic-Ivanic D, Cocco L, et al. Oncotarget. 2012; 3: 1068-1111.

185. Cervello M, McCubrey JA, Cusimano A, Lampiasi N, Azzolina A, Montalto G. Targeted therapy for hepatocellular carcinoma: novel agents on the horizon. Oncotarget. 2012; 3: 236-260.

186. Carracedo A, Ma L, Teruya-Feldstein J, Rojo F, Salmena L, Alimonti A, Egia A, Sasaki AT, Thomas G, Kozma SC, Papa A, Nardella C, Cantley LC, Baselga J, Pandolfi PP. Inhibition of mTORC1 leads to MAPK pathway activation through a PI3K-dependent feedback loop in human cancer. J Clin Invest. 2008; 118: 3065-3074.

187. Tamburini J, Green AS, Chapuis N, Bardet V, Lacombe C, Mayeux P, Bouscary D. Targeting translation in acute myeloid leukemia: a new paradigm for therapy? Cell Cycle. 2009; 8: 3893-3899.

188. Wang H, Brown J, Gu Z, Garcia CA, Liang R, Alard P, Beurel E, Jope RS, Greenway T, Martin M. Convergence of the mammalian target of rapamycin complex 1- and 
glycogen synthase kinase 3 - $\beta$-signaling pathways regulates the innate inflammatory response. J Immunol. 2011; 186: 5217-5226.

189. Inoki K, Ouyang H, Zhu T, Lindvall C, Wang Y, Zhang X, Yang Q, Bennett C, Harada Y, Stankunas K, Wang CY, He X, MacDougald OA, You M, Williams BO, Guan KL. TSC2 integrates Wnt and energy signals via a coordinated phosphorylation by AMPK and GSK3 to regulate cell growth. Cell. 2006; 126: 955-968.

190. Koo J, Yue P, Gal AA, Khuri FR, Sun SY. Maintaining glycogen synthase kinase-3 activity is critical for mTOR kinase inhibitors to inhibit cancer cell growth. Cancer Res. 2014 Mar 13

191. Huang J, Zhang Y, Bersenev A, O’Brien WT, Tong W, Emerson SG, Klein PS. Pivotal role for glycogen synthase kinase-3 in hematopoietic stem cell homeostasis in mice. J Clin Invest. 2009; 119: 3519-3529.

192. Yilmaz OH, Valdez R, Theisen BK, Guo W, Ferguson $\mathrm{DO}, \mathrm{Wu} \mathrm{H}$, Morrison SJ. Pten dependence distinguishes haematopoietic stem cells from leukaemia-initiating cells. Nature. 2006; 441: 475-482.

193. Chen C, Liu Y, Liu R, Ikenoue T, Guan KL, Liu Y, Zheng P. TSC-mTOR maintains quiescence and function of hematopoietic stem cells by repressing mitochondrial biogenesis and reactive oxygen species. J Exp Med. 2008; 205: 2397-2408.

194. Lee JY, Nakada D, Yilmaz OH, Tothova Z, Joseph NM, Lim MS, Gilliland DG, Morrison SJ. mTOR activation induces tumor suppressors that inhibit leukemogenesis and deplete hematopoietic stem cells after Pten deletion. Cell Stem Cell. 2010; 7: 593-605.

195. Adams GB, Scadden DT. The hematopoietic stem cell in its place. Nat Immunol. 2006; 7: 333-337.

196. Gan B, Hu J, Jiang S, Liu Y, Sahin E, Zhuang L, FletcherSananikone E, Colla S, Wang YA, Chin L, Depinho RA. Lkb1 regulates quiescence and metabolic homeostasis of haematopoietic stem cells. Nature. 2010; 468: 701-704.

197. Gurumurthy S, Xie SZ, Alagesan B, Kim J, Yusuf RZ, Saez B, Tzatsos A, Ozsolak F, Milos P, Ferrari F, Park PJ, Shirihai OS, Scadden DT, Bardeesy N. The Lkb1 metabolic sensor maintains haematopoietic stem cell survival. Nature. 2010; 468: 659-663.

198. Gan B, DePinho RA. mTORC1 signaling governs hematopoietic stem cell quiescence. Cell Cycle. 2009; 8: 1003-1006.

199. Chen C, Liu Y, Liu Y, Zheng P. mTOR regulation and therapeutic rejuvenation of aging hematopoietic stem cells. Sci Signal. 2009; 2: ra75.

200. Huang J, Nguyen-McCarty M, Hexner EO, DanetDesnoyers G, Klein PS. Maintenance of hematopoietic stem cells through regulation of Wnt and mTOR pathways. Nat Med. 2012; 18: 1778-1785.

201. Ito K, Carracedo A, Weiss D, Arai F, Ala U, Avigan DE, Schafer ZT, Evans RM, Suda T, Lee CH, Pandolfi PP.
A PML-PPAR-delta pathway for fatty acid oxidation regulates hematopoietic stem cell maintenance. Nat Med. 2012; 18: 1350-1358.

202. Burns KA, Vanden Heuvel JP. Modulation of PPAR activity via phosphorylation. Biochim Biophys Acta. 2007; 1771: 952-960.

203. Clapham JC, Arch JR. Thermogenic and metabolic antiobesity drugs: rationale and opportunities. Diabetes Obes Metab. 2007; 9: 259-275.

204. Narkar VA, Downes M, Yu RT, Embler E, Wang YX, Banayo E, Mihaylova MM, Nelson MC, Zou Y, Juguilon H, Kang H, Shaw RJ, Evans RM. AMPK and PPARdelta agonists are exercise mimetics. Cell. 2008; 134: 405-415.

205. Ito K, Bernardi R, Morotti A, Matsuoka S, Saglio G, Ikeda Y, Rosenblatt J, Avigan DE, Teruya-Feldstein J, Pandolfi PP. PML targeting eradicates quiescent leukaemia-initiating cells. Nature. 2008; 453: 1072-1078.

206. Bernardi R, Guernah I, Jin D, Grisendi S, Alimonti A, Teruya-Feldstein J, Cordon-Cardo C, Simon MC, Rafii S, Pandolfi PP. PML inhibits HIF-1alpha translation and neoangiogenesis through repression of mTOR. Nature. 2006; 442: 779-785.

207. Bernardi R, Papa A, Egia A, Coltella N, Teruya-Feldstein J, Signoretti S, Pandolfi PP. Pml represses tumour progression through inhibition of mTOR. EMBO Mol Med. 2011; 3: 249-257.

208. Sato N, Meijer L, Skaltsounis L, Greengard P, Brivanlou $\mathrm{AH}$. Maintenance of pluripotency in human and mouse embryonic stem cells through activation of Wnt signaling by a pharmacological GSK-3-specific inhibitor. Nat Med. 2004; 10: 55-63.

209. Doble BW, Patel S, Wood GA, Kockeritz LK, Woodgett JR. Functional redundancy of GSK-3alpha and GSK-3beta in Wnt/beta-catenin signaling shown by using an allelic series of embryonic stem cell lines. Dev Cell. 2007; 12: 957-971.

210. Gattinoni L, Klebanoff CA, Restifo NP. Pharmacologic induction of CD8 $+\mathrm{T}$ cell memory: better living through chemistry. Sci Transl Med. 2009; 1: 11 ps12.

211. Gattinoni L, Lugli E, Ji Y, Pos Z, Paulos CM, Quigley MF, Almeida JR, Gostick E, Yu Z, Carpenito C, Wang E, Douek DC, Price DA, June CH, Marincola FM, Roederer $\mathrm{M}$, et al. A human memory T cell subset with stem cell-like properties. Nat Med. 2011; 17: 1290-1297.

212. Gattinoni L, Klebanoff CA, Restifo NP. Paths to stemness: building the ultimate antitumour T cell. Nat Rev Cancer. 2012; 12: 671-684.

213. Clevers H, Nusse R. Wnt/ $\beta$-catenin signaling and disease. Cell. 2012; 149: 1192-1205.

214. Anastas JN, Moon RT. WNT signalling pathways as therapeutic targets in cancer. Nat Rev Cancer. 2013; 13: 11-26.

215. Wang J, Sinha T, Wynshaw-Boris A. Wnt signaling in mammalian development: lessons from mouse genetics. 
Cold Spring Harb Perspect Biol. 2012; 4:(5). pii: a007963. doi: 10.1101/cshperspect.a007963.

216. van Noort M, Meeldijk J, van der Zee R, Destree O, Clevers $\mathrm{H}$. Wnt signaling controls the phosphorylation status of beta-catenin. J Biol Chem. 2002; 277: 17901-17905.

217. Hagen T, Vidal-Puig A. Characterisation of the phosphorylation of beta-catenin at the GSK-3 priming site Ser45. Biochem Biophys Res Commun. 2002; 294: 324328.

218. Hagen T, di Daniel E, Culbert AA, Reith AD. Expression and characterization of GSK-3 mutants and their effect on beta-catenin phosphorylation in intact cells. J Biol Chem. 2002; 277: 23330-23335.

219. Liu C, Li Y, Semenov M, Han C, Baeg GH, Tan Y, Zhang Z, Lin X, He X. Control of beta-.catenin phosphorylation/ degradation by a dual-kinase mechanism. Cell. 2002; 108: 837-847.

220. Sakanaka C. Phosphorylation and regulation of beta-catenin by casein kinase I epsilon. J Biochem. 2002; 132: 697-703.

221. Yanagawa S, Matsuda Y, Lee JS, Matsubayashi H, Sese S, Kadowaki T, Ishimoto A. Casein kinase I phosphorylates the Armadillo protein and induces its degradation in Drosophila. EMBO J. 2002; 21: 1733-1742.

222. Ikeda S, Kishida S, Yamamoto H, Murai H, Koyama S, Kikuchi A. Axin, a negative regulator of the Wnt signaling pathway, forms a complex with GSK-3beta and beta-catenin and promotes GSK-3beta-dependent phosphorylation of beta-catenin. EMBO J. 1998; 17: 1371-1384.

223. Jho E, Lomvardas S, Costantini F. A GSK3beta phosphorylation site in axin modulates interaction with beta-catenin and Tcf-mediated gene expression. Biochem Biophys Res Commun. 1999; 266: 28-35.

224. Yamamoto H, Kishida S, Kishida M, Ikeda S, Takada S, Kikuchi A. Phosphorylation of axin, a Wnt signal negative regulator, by glycogen synthase kinase-3beta regulates its stability. J Biol Chem. 1999; 274: 10681-10684.

225. Rubinfeld B, Albert I, Porfiri E, Fiol C, Munemitsu S, Polakis. Binding of GSK3beta to the APC-beta-catenin complex and regulation of complex assembly. Science. 1996; 272: 1023-1026.

226. Schwarz-Romond T, Asbrand C, Bakkers J, Kuhl M, Schaeffer HJ, Huelsken J, Behrens J, Hammerschmidt M, Birchmeier W. The ankyrin repeat protein Diversin recruits Casein kinase I epsilon to the beta-catenin degradation complex and acts in both canonical Wnt and Wnt/JNK signaling. Genes Dev. 2002; 16: 2073-2084.

227. Bax B, Carter PS, Lewis C, Guy AR, Bridges A, Tanner R, Pettman G, Mannix C, Culbert AA, Brown MJ, Smith DG, Reith AD. The structure of phosphorylated GSK-3beta complexed with a peptide, FRATtide, that inhibits betacatenin phosphorylation. Structure. 2001; 9: 1143-1152.

228. Ferkey DM, Kimelman D. Glycogen synthase kinase-3 beta mutagenesis identifies a common binding domain for GBP and Axin. J Biol Chem. 2002; 277: 16147-16152.
229. Franca-Koh J, Yeo M, Fraser E, Young N, Dale TC. The regulation of glycogen synthase kinase- 3 nuclear export by Frat/GBP. J Biol Chem. 2002; 277: 43844-43848.

230. Ding VW, Chen RH, McCormick F. Differential regulation of glycogen synthase kinase 3beta by insulin and Wnt signaling. J Biol Chem. 2000; 275: 32475-32481.

231. Yuan H, Mao J, Li L, Wu D. Suppression of glycogen synthase kinase activity is not sufficient for leukemia enhancer factor-1 activation. J Biol Chem. 1999; 274: 30419-30423.

232. Zeng X, Tamai K, Doble B, Li S, Huang H, Habas R, Okamura H, Woodgett J, He X. A dual-kinase mechanism for Wnt co-receptor phosphorylation and activation. Nature. 2005; 438: 873-877.

233. Zeng X, Huang H, Tamai K, Zhang X, Harada Y, Yokota C, Almeida K, Wang J, Doble B, Woodgett J, WynshawBoris A, Hsieh JC, He X. Initiation of Wnt signaling: control of Wnt coreceptor Lrp6 phosphorylation/activation via frizzled, dishevelled and axin functions. Development. 2008; 135: 367-375.

234. MacDonald BT, Tamai K, He X. Wnt/beta-catenin signaling: components, mechanisms, and diseases. Dev Cell. 2009; 17: 9-26.

235. Davidson G, Wu W, Shen J, Bilic J, Fenger U, Stannek P, Glinka A, Niehrs C. Casein kinase 1 gamma couples Wnt receptor activation to cytoplasmic signal transduction. Nature. 2005; 438: 867-872.

236. Wu D, Pan W. GSK3: a multifaceted kinase in Wnt signaling. Trends Biochem Sci. 2010; 35: 161-168.

237. Major MB, Camp ND, Berndt JD, Yi X, Goldenberg SJ, Hubbert C, Biechele TL, Gingras AC, Zheng N, Maccoss MJ, Angers S, Moon RT. Wilms tumor suppressor WTX negatively regulates WNT/beta-catenin signaling. Science. 2007; 316: 1043-1046.

238. Valvezan AJ, Zhang F, Diehl JA, Klein PS. Adenomatous polyposis coli (APC) regulates multiple signaling pathways by enhancing glycogen synthase kinase-3 (GSK-3) activity. J Biol Chem. 2012; 287: 3823-3832.

239. Desbois-Mouthon C, Blivet-Van Eggelpoël MJ, Beurel E, Boissan M, Delélo R, Cadoret A, Capeau J. Dysregulation of glycogen synthase kinase-3beta signaling in hepatocellular carcinoma cells. Hepatology. 2002;36(6):1528-36.

240. Huang KT, Huang YH, Li P, He B, Chen ZK, Yu X, Chen JO, Zhang QY, Shi HQ, Shan YF. The correlation between TSC 2 and GSK3 $\beta$ levels, and outcomes of patients with hepatocellular carcinoma treated by hepatectomy. Hepatol Res. 2013 Oct 7. doi: 10.1111/hepr.12256. [Epub ahead of print].

241. Huang KT, Huang YH, Li P, He B, Chen ZK, Yu X, Chen JO, Zhang QY, Shi HQ, Shan YF. The correlation between TSC 2 and GSK3 $\beta$ levels, and outcomes of patients with hepatocellular carcinoma treated by hepatectomy. Hepatol Res. 2013 Oct 7. doi: 10.1111/hepr.12256. [Epub ahead of print]. 
242. Desbois-Mouthon C, Blivet-Van Eggelpoël MJ, Beurel E, Boissan M, Delélo R, Cadoret A, Capeau J. Dysregulation of glycogen synthase kinase-3beta signaling in hepatocellular carcinoma cells. Hepatology. 2002; 36: 1528-1536.

243. Ding Q, Xia W, Liu JC, Yang JY, Lee DF, Xia J, Bartholomeusz G, Li Y, Pan Y, Li Z, Bargou RC, Qin J, Lai CC, Tsai FJ, Tsai CH, Hung MC. Erk associates with and primes GSK-3beta for its inactivation resulting in upregulation of beta-catenin. Mol Cell. 2005; 19(2):159-70.

244. Cai X1, Li M, Vrana J, Schaller MD. Glycogen synthase kinase 3-beta and extracellular signal-regulated kinasedependent phosphorylation of paxillin regulates cytoskeletal rearrangement. Mol Cell Biol. 2006; 26:2857-2868.

245. Liu J, Ding X, Tang J, Cao Y, Hu P, Zhou F, Shan X, Cai X, Chen Q, Ling N, Zhang B, Bi Y, Chen K, Ren H, Huang A, He TC, Tang N. Enhancement of canonical Wnt $/ \beta$ catenin signaling activity by $\mathrm{HCV}$ core protein promotes cell growth of hepatocellular carcinoma cells. PLoS One. 2011; 6(11):e27496.

246. Chen J, Chan AW, To KF, Chen W, Zhang Z, Ren J, Song C, Cheung YS, Lai PB, Cheng SH, Ng MH, Huang A, Ko BC. SIRT2 overexpression in hepatocellular carcinoma mediates epithelial to mesenchymal transition by protein kinase $\mathrm{B} /$ glycogen synthase kinase- $3 \beta / \beta$-catenin signaling. Hepatology. 2013; 57(6):2287-98.

247. Merksamer PI. Liu Y. He W. Hirschey MD. Chen D. Verdin E. The sirtuins, oxidative stress and aging: an emerging link. Aging. 2013; 5: 144-150.

248. Shakoori A, Mai W, Miyashita K, Yasumoto K, Takahashi Y, Ooi A, Kawakami K, Minamoto T. Inhibition of GSK3 beta activity attenuates proliferation of human colon cancer cells in rodents. Cancer Sci. 2007; 98: 1388-1393.

249. Kunnimalaiyaan M, Vaccaro AM, Ndiaye MA, Chen H. Inactivation of glycogen synthase kinase-3 $\beta$, a downstream target of the raf-1 pathway, is associated with growth suppression in medullary thyroid cancer cells. Mol Cancer Ther. 2007;6:1151-8.

250. Smalley KS, Contractor R, Haass NK, Kulp AN, AtillaGokcumen GE, Williams DS, Bregman H, Flaherty KT, Soengas MS, Meggers E, Herlyn M. An organometallic protein kinase inhibitor pharmacologically activates p53 and induces apoptosis in human melanoma cells. Cancer Res. 2007; 67: 209-217.

251. Miyashita K, Kawakami K, Nakada M, Mai W, Shakoori A, Fujisawa H, Hayashi Y, Hamada J, Minamoto T. Potential therapeutic effect of glycogen synthase kinase 3 beta inhibition against human glioblastoma. Clin Cancer Res. 2009;15: 887-897.

252. Pyko IV, Nakada M, Sabit H, Teng L, Furuyama N, Hayashi Y, Kawakami K, Minamoto T, Fedulau AS, Hamada J. Glycogen synthase kinase $3 \beta$ inhibition sensitizes human glioblastoma cells to temozolomide by affecting O6-methylguanine DNA methyltransferase promoter methylation via c-Myc signaling. Carcinogenesis. 2013; 34:
2206-2217.

253. Kitano A, Shimasaki T, Chikano Y, Nakada M, Hirose M, Higashi T, Ishigaki Y, Endo Y, Takino T, Sato H, Sai Y, Miyamoto K, Motoo Y, Kawakami K, Minamoto T. Aberrant glycogen synthase kinase $3 \beta$ is involved in pancreatic cancer cell invasion and resistance to therapy. PLoS One. 2013;8(2):e55289.

254. Mai W, Kawakami K, Shakoori A, Kyo S, Miyashita K, Yokoi K, Jin M, Shimasaki T, Motoo Y, Minamoto T. Deregulated GSK3beta sustains gastrointestinal cancer cells survival by modulating human telomerase reverse transcriptase and telomerase. Clin Cancer Res. 2009; 15: 6810-6819.

255. Beurel E, Blivet-Van Eggelpoël MJ, Kornprobst M, Moritz S, Delelo R, Paye F, Housset C, Desbois-Mouthon C. Glycogen synthase kinase-3 inhibitors augment TRAILinduced apoptotic death in human hepatoma cells. Biochem Pharmacol. 2009; 77: 54-65.

256. Mai W, Kawakami K, Shakoori A, Kyo S, Miyashita K, Yokoi K, Jin M, Shimasaki T, Motoo Y, Minamoto T. Deregulated GSK3beta sustains gastrointestinal cancer cells survival by modulating human telomerase reverse transcriptase and telomerase. Clin Cancer Res. 2009; 15: 6810-6819.

257. Beurel E, Blivet-Van Eggelpoël MJ, Kornprobst M, Moritz S, Delelo R, Paye F, Housset C, Desbois-Mouthon C. Glycogen synthase kinase-3 inhibitors augment TRAILinduced apoptotic death in human hepatoma cells. Biochem Pharmacol. 2009; 77: 54-65.

258. Fuentealba LC, Eivers E, Ikeda A, Hurtado C, Kuroda H, Pera EM, De Robertis EM. Integrating patterning signals: Wnt/GSK3 regulates the duration of the BMP/Smad1 signal. Cell. 2007; 131: 980-993.

259. Ng JM, Curran T. The Hedgehog's tale: developing strategies for targeting cancer. Nat Rev Cancer. 2011; 11: 493-501.

260. Metcalfe C, de Sauvage FJ. Hedgehog fights back: mechanisms of acquired resistance against smoothened antagonists. Cancer Res. 2011; 71: 5057-5061.

261. Takenaka K, Kise Y, Miki H. GSK3beta positively regulates Hedgehog signaling through Sufu in mammalian cells. Biochem Biophys Res Commun. 2007; 353: 501-508.

262. Kogerman P, Grimm T, Kogerman L, Krause D, Undén AB, Sandstedt B, Toftgård R, Zaphiropoulos PG. Mammalian suppressor-of-fused modulates nuclear-cytoplasmic shuttling of Gli-1. Nat Cell Biol. 1999; 1: 312-319.

263. Kise Y, Morinaka A, Teglund S, Miki H. Sufu recruits GSK3beta for efficient processing of Gli3. Biochem Biophys Res Commun. 2009; 387: 569-574.

264. Bray SJ. Notch signalling: a simple pathway becomes complex. Nat Rev Mol Cell Biol. 2006; 7: 678-689.

265. Schroeter EH, Kisslinger JA, Kopan R. Notch-1 signalling requires ligand-induced proteolytic release of intracellular domain. Nature. 1998; 393: 382-386. 
266. De Strooper B, Annaert W, Cupers P, Saftig P, Craessaerts K, Mumm JS, Schroeter EH, Schrijvers V, Wolfe MS, Ray WJ, Goate A, Kopan R. A presenilin-1-dependent gamma-secretase-like protease mediates release of Notch intracellular domain. Nature. 1999; 398: 518-522.

267. Struhl G, Adachi A. Nuclear access and action of notch in vivo. Cell. 1998; 93: 649-660.

268. Ohtsuka T, Ishibashi M, Gradwohl G, Nakanishi S, Guillemot F, Kageyama R. Hes1 and Hes5 as notch effectors in mammalian neuronal differentiation. EMBO J. 1999; 18: 2196-2207.

269. Jouve C, Palmeirim I, Henrique D, Beckers J, Gossler A, Ish-Horowicz D, Pourquié O. Notch signalling is required for cyclic expression of the hairy-like gene HES1 in the presomitic mesoderm. Development. 2000; 127: 14211429.

270. Song J, Park S, Kim M, Shin I. Down-regulation of Notchdependent transcription by Akt in vitro. FEBS Lett. 2008; 582: 1693-1699.

271. Han X, Ju JH, Shin I. Glycogen synthase kinase 3-beta phosphorylates novel S/T-P-S/T domains in Notch1 intracellular domain and induces its nuclear localization. Biochem Biophys Res Commun. 2012; 423: 282-288.

272. Jin YH, Kim H, Oh M, Ki H, Kim K. Regulation of Notch1/ NICD and Hes1 expressions by GSK-3alpha/beta. Mol Cells. 2009; 27: 15-19.

273. Jin YH, Kim H, Ki H, Yang I, Yang N, Lee KY, Kim N, Park HS, Kim K. Beta-catenin modulates the level and transcriptional activity of Notch1/NICD through its direct interaction. Biochim Biophys Acta. 2009; 1793: 290-299.

274. Espinosa L, Inglés-Esteve J, Aguilera C, Bigas A. Phosphorylation by glycogen synthase kinase-3 beta down-regulates Notch activity, a link for Notch and Wnt pathways. J Biol Chem. 2003; 278: 32227-32235.

275. Stambolic V, Ruel L, Woodgett JR. Lithium inhibits glycogen synthase kinase-3 activity and mimics wingless signalling in intact cells. Curr Biol. 1996; 6: 1664-1668.

276. Howland RH. Lithium: underappreciated and underused? J Psychosoc Nurs Ment Health Serv. 2007; 45: 13-17.

277. Ricci P, Bandini G, Franchi P, Motta MR, Visani G, Calamandrei G. Haematological effects of lithium carbonate: a study in 56 psychiatric patients. Haematologica. 1981; 66: 627-633.

278. Boggs DR, Joyce RA. The hematopoietic effects of lithium. Semin Hematol. 1983; 20: 129-138.

279. Joyce RA. Sequential effects of lithium on haematopoiesis. Br J Haematol. 1984; 56: 307-321.

280. Ballin A, Lehman D, Sirota P, Litvinjuk U, Meytes D. Increased number of peripheral blood CD34+ cells in lithium-treated patients. Br J Haematol. 1998; 100: 219221.

281. Klein PS, Melton DA. A molecular mechanism for the effect of lithium on development. Proc Natl Acad Sci USA. 1996; 93: 8455-8459.
282. Hedgepeth CM, Conrad LJ, Zhang J, Huang HC, Lee VM, Klein PS. Activation of the Wnt signaling pathway: a molecular mechanism for lithium action. Dev Biol. 1997; 185: 82-91.

283. Phiel CJ, Klein PS. Molecular targets of lithium action. Annu Rev Pharmacol Toxicol. 2001; 41: 789-813.

284. Ougolkov AV, Billadeau DD. Inhibition of glycogen synthase kinase-3. Methods Mol Biol. 2008; 468: 67-75.

285. Ougolkov AV, Bone ND, Fernandez-Zapico ME, Kay NE, Billadeau DD. Inhibition of glycogen synthase kinase-3 activity leads to epigenetic silencing of nuclear factor kappaB target genes and induction of apoptosis in chronic lymphocytic leukemia B cells. Blood. 2007; 110: 735-742.

286. Cao Q, Lu X, Feng YJ. Glycogen synthase kinase-3beta positively regulates the proliferation of human ovarian cancer cells. Cell Res. 2006; 16: 671-677.

287. Shakoori A, Mai W, Miyashita K, Yasumoto K, Takahashi Y, Ooi A, Kawakami K, Minamoto T. Inhibition of GSK-3 beta activity attenuates proliferation of human colon cancer cells in rodents. Cancer Sci. 2007; 98: 1388-1393.

288. Miyashita K, Kawakami K, Nakada M, Mai W, Shakoori A, Fujisawa H, Hayashi Y, Hamada J, Minamoto T. Potential therapeutic effect of glycogen synthase kinase 3 beta inhibition against human glioblastoma. Clin Cancer Res. 2009; 15: 887-897.

289. Mirlashari MR, Randen I, Kjeldsen-Kragh J. Glycogen synthase kinase-3 (GSK-3) inhibition induces apoptosis in leukemic cells through mitochondria-dependent pathway. Leuk Res. 2012; 36: 499-508.

290. Huang HS, Liu ZM, Cheng YL. Involvement of glycogen synthase kinase-3 $\beta$ in arsenic trioxide-induced p21 expression. Toxicol Sci. 2011; 121: 101-109.

291. Alao JP, Stavropoulou AV, Lam EW, Coombes RC. Role of glycogen synthase kinase 3 beta (GSK3beta) in mediating the cytotoxic effects of the histone deacetylase inhibitor trichostatin A (TSA) in MCF-7 breast cancer cells. Mol Cancer. 2006; 5: 40.

292. Urbanska K, Trojanek J, Del Valle L, Eldeen MB, Hofmann F, Garcia-Echeverria C, Khalili K, Reiss K. Inhibition of IGF-I receptor in anchorage-independence attenuates GSK3 beta constitutive phosphorylation and compromises growth and survival of medulloblastoma cell lines. Oncogene. 2007; 26: 2308-2317.

293. Dravid G, Ye Z, Hammond H, Chen G, Pyle A, Donovan $\mathrm{P}, \mathrm{Yu} \mathrm{X}$, Cheng L. Defining the role of Wnt/beta-catenin signaling in the survival, proliferation, and self-renewal of human embryonic stem cells. Stem Cells. 2005; 23: 14891501.

294. Bakre MM, Hoi A, Mong JC, Koh YY, Wong KY, Stanton LW. Generation of multipotential mesendodermal progenitors from mouse embryonic stem cells via sustained Wnt pathway activation. J Biol Chem. 2007; 282: 3170331712.

295. Doble BW, Woodgett JR. Exploring Pluripotency with 
Chemical Genetics. Cell Stem Cell. 2009; 4: 98-100.

296. Riobo NA, Lu K, Ai X, Haines GM, Emerson CP Jr. Phosphoinositide 3-kinase and Akt are essential for Sonic hedgehog signaling, Proc Nat Acad Sci USA. 2006; 103: 4505-4510.

297. Bone HK, Damiano T, Bartlett S, Perry A, Letchford J, Sanchez Ripoli Y, Nelson AS, Welham MJ. Involvement of GSK-3 in regulation of murine embryonic stem cell selfrenewal revealed by a series of bisindolylmaleimides. Chem Biol. 2009; 16: 15-27.

298. Miyashita K, Nakada M, Shakoori A, Ishigaki Y, Shimasaki T, Motoo Y, Kawakami K, Minamoto T. An emerging strategy for cancer treatment targeting aberrant glycogen synthase kinase 3 beta. Anticancer Agents Med Chem. 2009; 9: 1114-1122.

299. Panka DJ, Cho DC, Atkins MB, Mire JW. GSK-3beta inhibition enhances sorafenib-induced apoptosis in melanoma cell lines. Journal of Biological Chemistry. 2008; 283: 726-732.

300. Moore GJ, Cortese BM, Glitz DA, Zajac-Benitez C, Quiroz JA, Uhde TW, Drevets WC, Manji HK. A longitudinal study of the effects of lithium treatment on prefrontal and subgenual prefrontal gray matter volume in treatmentresponsive bipolar disorder patients. J Clin Psychiatry. 2009; 70: 699-705.

301. Ban JO, Oh JH, Son SM, Won D, Song HS, Han SB, Moon DC, Kang KW, Song MJ, Hong JT. Troglitazone, a PPAR agonist, inhibits human prostate cancer cell growth through inactivation of $\mathrm{NF} \kappa \mathrm{B}$ via suppression of GSK-3 $\beta$ expression. Cancer Biol Ther. 2011; 12: 288-96.

302. Georgievska B1, Sandin J, Doherty J, Mörtberg A, Neelissen J, Andersson A, Gruber S, Nilsson Y, Schött P, Arvidsson PI, Hellberg S, Osswald G, Berg S, Fälting J, Bhat RV. AZD1080, a novel GSK3 inhibitor, rescues synaptic plasticity deficits in rodent brain and exhibits peripheral target engagement in humans. J Neurochem. 2013; 125:446-456.

303. Marsell R1, Sisask G, Nilsson Y, Sundgren-Andersson AK, Andersson U, Larsson S, Nilsson O, Ljunggren O, Jonsson KB. GSK-3 inhibition by an orally active small molecule increases bone mass in rats. Bone. 2012; 50: 619-627.

304. Meijer L, Skaltsounis AL, Magiatis P, Polychronopoulos P, Knockaert M, Leost M, Ryan XP, Vonica CA, Brivanlou A, Dajani R, Crovace C, Tarricone C, Musacchio A, Roe SM, Pearl L, Greengard P. GSK-3-selective inhibitors derived from Tyrian purple indirubins. Chem Biol. 2003; 10: 12551266.

305. Bennett CN, Longo KA, Wright WS, Suva LJ, Lane $\mathrm{TF}$, Hankenson KD, MacDougald OA. Regulation of osteoblastogenesis and bone mass by Wnt10b. Proc Natl Acad Sci U S A. 2005; 102: 3324-3329.

306. Ring DB, Johnson KW, Henriksen EJ, Nuss JM, Goff D, Kinnick TR, Ma ST, Reeder JW, Samuels I, Slabiak T, Wagman AS, Hammond ME, Harrison SD. Selective glycogen synthase kinase 3 inhibitors potentiate insulin activation of glucose transport and utilization in vitro and in vivo. Diabetes. 2003; 52: 588-595.

307. Zamek-Gliszczynski MJ1, Abraham TL, Alberts JJ, Kulanthaivel P, Jackson KA, Chow KH, McCann DJ, $\mathrm{Hu} \mathrm{H}$, Anderson S, Furr NA, Barbuch RJ, Cassidy KC. Pharmacokinetics, metabolism, and excretion of the glycogen synthase kinase-3 inhibitor LY2090314 in rats, dogs, and humans: a case study in rapid clearance by extensive metabolism with low circulating metabolite exposure. Drug Metab Dispos. 2013; 41:714-726.

308. Kubic JD, Mascarenhas JB, Iizuka T, Wolfgeher D, Lang D. GSK-3 promotes cell survival, growth, and PAX3 levels in human melanoma cells. Mol Cancer Res. 2012; 10: 10651076.

309. Piazza F, Manni S, Tubi LQ, Montini B, Pavan L, Colpo A, Gnoato M, Cabrelle A, Adami F, Zambello R, Trentin L, Gurrieri C, Semenzato G. Glycogen Synthase Kinase-3 regulates multiple myeloma cell growth and bortezomibinduced cell death. BMC Cancer. 2010; 10: 526.

310. Dickey A, Schleicher S, Leahy K, Hu R, Hallahan D, Thotala DK. GSK-3 $\beta$ inhibition promotes cell death, apoptosis, and in vivo tumor growth delay in neuroblastoma Neuro-2A cell line. J Neurooncol. 2011; 104(1): 145-53. doi: 10.1007/s11060-010-0491-3.

311. Beurel E, Blivet-Van Eggelpoël MJ, Kornprobst M, Moritz S, Delelo R, Paye F, Housset C, Desbois-Mouthon C. Glycogen synthase kinase-3 inhibitors augment TRAILinduced apoptotic death in human hepatoma cells. Biochem Pharmacol. 2009; 77(1):54-65. doi: 10.1016/j. bcp.2008.09.026.

312. Aguilar-Morante D, Morales-Garcia JA, Sanz-SanCristobal M, Garcia-Cabezas MA, Santos A, Perez-Castillo A. Inhibition of glioblastoma growth by the thiadiazolidinone compound TDZD-8. PLoS One. 2010; 5(11): e13879.

313. Zeng FY, Dong H, Cui J, Liu L, Chen T. Glycogen synthase kinase 3 regulates PAX3-FKHR-mediated cell proliferation in human alveolar rhabdomyosarcoma cells. Biochem Biophys Res Commun. 2010; 391: 1049-1055.

314. del Ser T, Steinwachs KC, Gertz HJ, Andrés MV, GómezCarrillo B, Medina M, Vericat JA, Redondo P, Fleet D, León T. Treatment of Alzheimer's disease with the GSK-3 inhibitor tideglusib: a pilot study. J Alzheimers Dis. 2013; 33: 205-215. 